\title{
First records of trace fossils from the Lake District, southwestern Turkey
}

\author{
Jan KRESTEN NieLSEN, MuHITTIn GÖRMÜş, KUBILAY UYSAL \& SŰVEYLA KANBUR
}

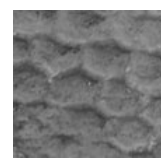

\begin{abstract}
Important new ichnological data was obtained from the Isparta Çay Formation (Triassic to early Cretaceous), Koçtepe Formation (middle Paleocene to Early Eocene), Isparta Formation (Early to Middle Eocene) and İncesu Formation (Middle Eocene to Early Oligocene). These formations are significantly exposed in the Eğirdir, Gönen and Isparta regions within the northern part of the Isparta Angle. An overview of the stratigraphy and its trace-fossil bearing formations and microfossil content is presented together with recommendations. The density and diversity of trace fossils vary between and within these formations, which originated in deep-marine shelf slope and shelf environments of the Neotethys ocean. Changes in the frequency of abrupt turbiditic deposition, oxygenation of the bottom water and possibly food availability are reflective in the trace fossil distribution. The trace fossils of the Isparta Çay, Koçtepe and Isparta formations are typical of deep-marine settings with occasional high-energy turbiditic conditions. The Isparta Çay Formation (Paleodictyon ichnosubfacies) is seen as the bedrocks of the region, whereas the Isparta Formation (Ophiomorpha rudis ichnosubfacies) overlies conformably the Koçtepe Formation (Nereites and Arenicolites ichnofacies). The İncesu Formation is laterally interlaced with the Isparta Formation. A high diversity of trace fossils occurs in the İncesu Formation (Zoophycos ichnofacies), which was formed in an outer shelf environment. Findings from previous ichnological investigations in Turkey are compiled and compared with the present results from the Isparta Angle. Keywords: stratigraphy, trace fossils, ethology, ichnofacies, shelf, bathyal, Turkey.
\end{abstract}

NIELSEN, J.K., GÖRMÜȘ, M., UYSAL, K. \& KANBUR, S. 2010. First records of trace fossils from the Lake District, southwestern Turkey. Bulletin of Geosciences 85(4), 691-708 (10 figures, 2 tables). Czech Geological Survey, Prague. ISSN 1214-1119. Manuscript received Febuary 18, 2010; accepted in revised form June 11, 2010; published online September 17, 2010; issued December 20, 2010.

Jan Kresten Nielsen, Statoil ASA, TNE SST Reservoir Technology, IOR Studies, P.O. Box 273, NO-7501 Stjørdal, Norway; bioerosion@yahoo.dk • Muhittin Görmüș, Kubilay Uysal and Süveyla Kanbur, SDÜ Mühendislik-Mimarlık Fakültesi, Jeoloji Mühendisliği Bölümü, Çünür-Isparta, Turkey

The development of concepts concerning the tectonic evolution of the Neotethys in the Eastern Mediterranean region is notably connected with the Isparta Angle in southwestern Turkey (Fig. 1). The investigation area, which is located between Gönen (Isparta) and Ağlasun (Burdur) in the northern part of the Isparta Angle, is known for its Mesozoic-Tertiary sediments. Previous studies define the Isparta Angle as a complex geological structure including various autochthonous and allochthonous units (e.g., Monod 1976; Gutnic et al. 1979; Koçyiğit 1981, 1983, 1984; Țenel 1997; Yalçınkaya et al. 1986; Yalçınkaya 1989; Karaman 1990, 1994; Robertson 1993; Görmüş \& Özkul 1995; Yağmurlu et al. 1997). The allochthonous units of the Isparta Angle comprise the Antalya Complex and reflect a Mesozoic-Tertiary polyphase deformational history (e.g., Robertson et al. 2003). The northern part of the Isparta Angle is particularly well known for its Paleocene to Miocene marine successions located between Gönen (Isparta) and Ağlasun (Burdur). These successions, which are composed of shelf and shelf slope deposits, are geographically extensive and represented by a thickness of several hundred metres. Most researchers used and followed the geological maps and the identified geological units of Gutnic et al. (1979), Yalçınkaya et al. (1986) and Șenel (1997). The previous work resulted in a number of problems being identified regarding boundary relationships, geological ages and palaeoenvironmental interpretation of the formations (Görmüș et al. 2001a). There has been no common agreement so far on the stratigraphy and tectonics of the region.

The geology of the Isparta Angle has received increasing attention during recent years; however, the trace fossils of the Triassic to Oligocene successions have not previously been studied in detail (Fig. 1). Preliminary findings of trace fossils were breifly commented on by Görmüș et al. $(2003,2008)$ and are reported further herein. The diversity and density of trace fossils, and models of ancient behavioural activity, can provide crucial knowledge about successions which are poor in skeletal and shelly fossils 

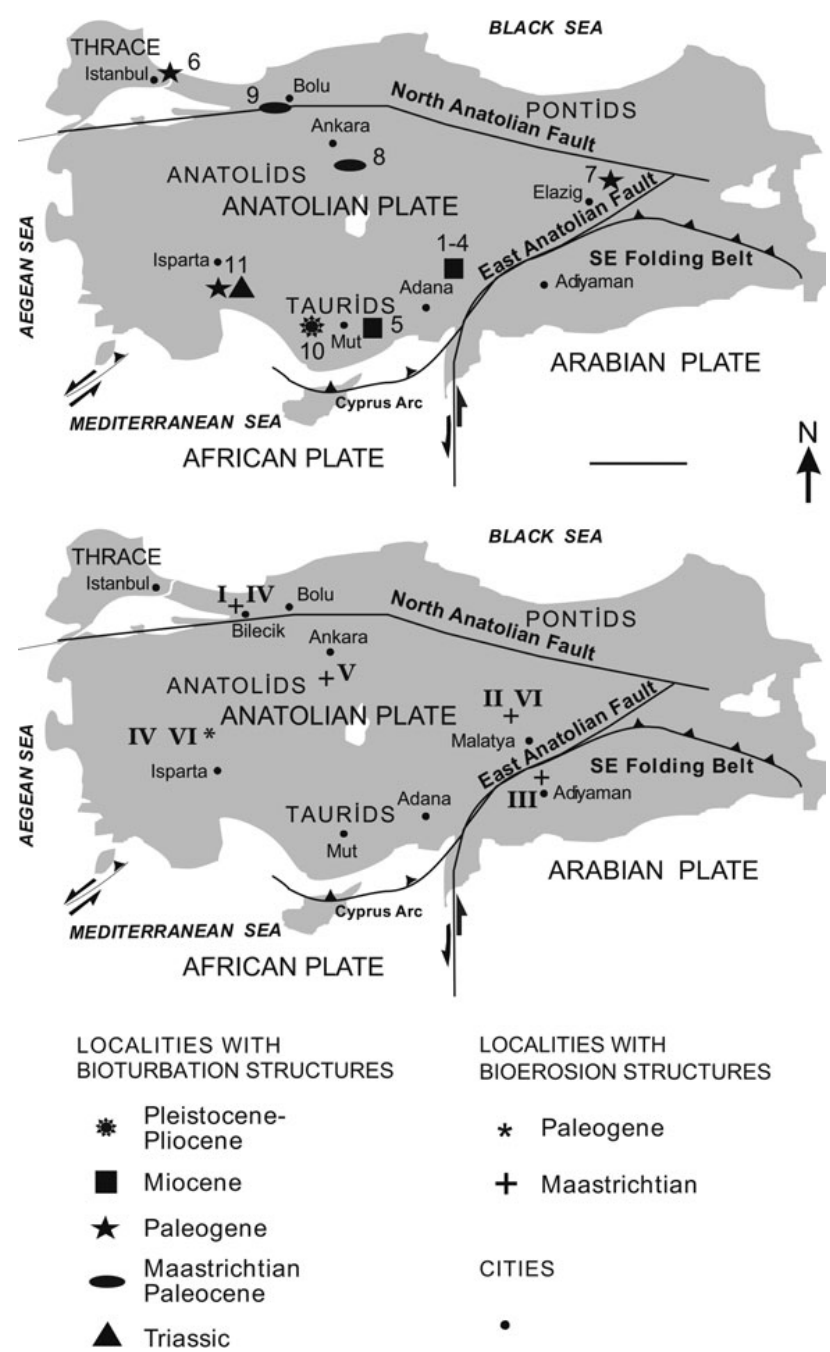

Figure 1. Geographical overview of macroscopic bioturbation structures presented herein and in previous studies: 1, 2- Uchman \& Demircan (1999a, b), 3 - Demircan \& Toker (2003), 4 - Demircan \& Toker (2004), 5 - Uchman et al. (2002), 6 - Demircan (2008), 7 - Özkul (1993), 8 - Yildiz et al. (2000), 9 - Sevim (2003), 10 - Yildiz et al. (2003), 11 - this study. Investigations of microscopic bioerosion structures are also shown: I - Görmüș \& Sagular (1998), II - Görmüș \& Meriç (2000), III - Meriç \& Görmüș (2001), IV - Nielsen \& Görmüș (2004), V - Görmüș et al. (2005), VI - Görmüș \& Nielsen (2006).

(e.g., Nielsen et al. 1996). The primary objective of this paper is therefore to present the ichnological characteristics of carbonate and siliciclastic successions from the Mesozoic and Tertiary of the Isparta Angle. Previously published findings from Turkey are also summarised and presented.

\section{Geological setting}

Although previous work indicated the problems mentioned above, the following summarizes the stratigraphical framework of the region (Figs 2,3). Based on the previous litera- ture and our fieldwork observations, the autochthonous units are as follows from bottom to top: (1) Jurassic to Cretaceous Davras Limestone (synonym Beydağları limestone, Yalçınkaya et al. 1986) including Söbüdağ Limestone Member, Upper Cretaceous, (2) Çiğdemtepe Formation, sheet limestones (synonym Senirce limestone, Karaman et al. 1988), ?Campanian-Maastrichtian, (3) Koçtepe Formation, clastics (synonym Kızılkırma Formation, Karaman et al. 1988), Upper Paleocene, (4) Isparta Formation, marls and clastics (synonym: Isparta flysch, Gutnic et al. 1979), Upper Paleocene to Eocene, (5) İncesu Formation, coarse clastics, Eocene to Oligocene, (6) Karabayır Formation, limestones (synonym İmrezi limestone, Yalçınkaya 1989, Yazır limestone, Karaman 1990), Lower Miocene, (7) Güneyce Formation, clastics (synonym Aglasun Formation, Yalçınkaya 1989), Lower to Middle Miocene, (8) Gökdere Formation, medium to coarse grained clastics, Middle Miocene, (9) Terrestrial, PlioceneQuaternary Gölcük Volcanics, (10) Terrestrial Atabey Conglomerate, Pliocene-Quaternary in age, and (11) recent sediments. The allochthonous units are known as the Antalya nappes and Lycian nappes (Figs 2, 3). The formation names have been adopted from the previous work carried out at different places in the region (Poisson \& Poignant 1974, Gutnic et al. 1979, Akbulut 1980, Koçyiğit 1980, Sariiz 1985). The first names have been used according to the stratigraphical rules (Hedberg 1976).

The Antalya and Lycian nappes are related to Cretaceous-Miocene compression (Koçyiğit 1983, 1984; Şenel 1984, 1997; Robertson 1993; Glover \& Robertson 1998; Robertson 2000; Temiz et al. 2001; Poisson et al. 2003a, b; Țentürk \& Yağmurlu 2003). However, the horst and graben systems controlling the Burdur, Eğirdir and Kovada Lake formations exist as a result of post-Miocene tension (Koçyiğit 1983, 1984, 2000; Yağmurlu et al. 1997; Poisson et al. 2003a, b; Robertson et al. 2003), and it is known as the neotectonic period. In addition, volcanic dykes formed by the different tensional forces are also seen in the angle.

\section{Material and methods}

A number of localities with Mesozoic to Cenozoic successions were systematically examined during fieldwork for the presence of trace fossils. The studied successions are from bottom to top as follows: Triassic limestones of the Antalya nappes, Paleocene to Eocene mudstones of the Koçtepe Formation, marls of the Isparta Formation, and calcarenites of the İncesu Formation (Fig. 3). The localities included road sections as well as natural outcrops (Fig. 1). About fifty hand-picked samples were obtained from these localities. Selected samples are housed in the Department of Geological Engineering of Süleyman Demirel University (Isparta). 


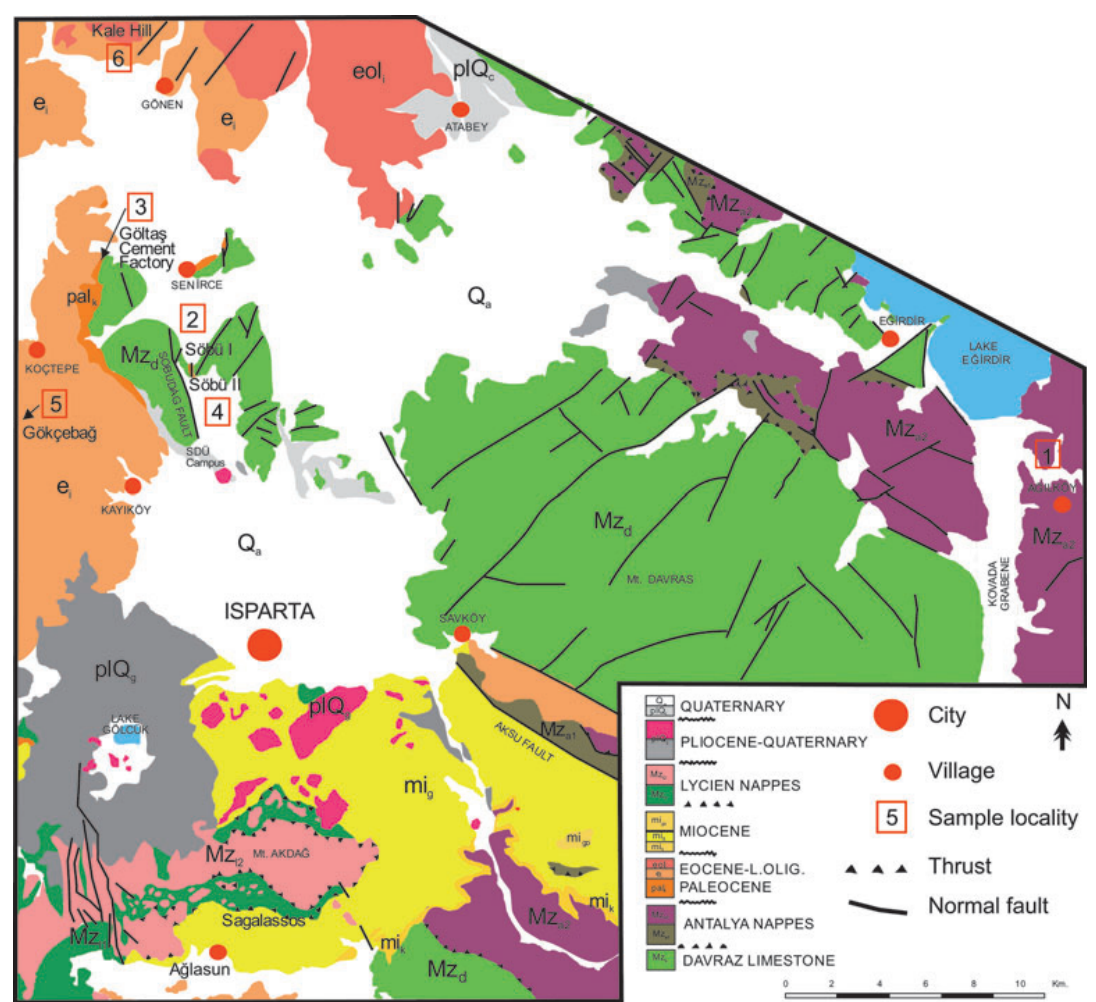

Figure 2. Geological map of the studied Ağlasun, Eğirdir, Gönen and Isparta regions and the geographic distribution of Triassic to early Cretaceous and Paleocene to Miocene sedimentary successions. Localities are indicated by rectangle symbols (modified from Gutnic et al. 1979, Şenel 1997).

Investigation of the trace fossils included macroscopic and microscopic observation. The term margin is used for the boundary surface between a trace fossil and the surrounding substrate (Goldring \& Pollard 1996, Nielsen \& Nielsen 2001). Following the guidelines given by Bertling et al. (2006), the identification of ichnotaxa is based exclusively on morphological features. Density of the trace fossils is described by using a semi-quantitative scheme, i.e., low, moderate and high. Preservation of the trace fossils is described using the terminology developed by Seilacher (1964a, b).

\section{Stratigraphy and ichnology}

Although various geological units have been identified in the region, here we only present trace fossil bearing formations. They come from Triassic to Oligocene sediments (Figs 2, 3). These trace fossils have until now not been documented.

\section{Triassic to Early Cretaceous}

The Antalya nappes are composed of various geological units (Gutnic et al. 1979, Robertson 1993, Vrielynck et al.

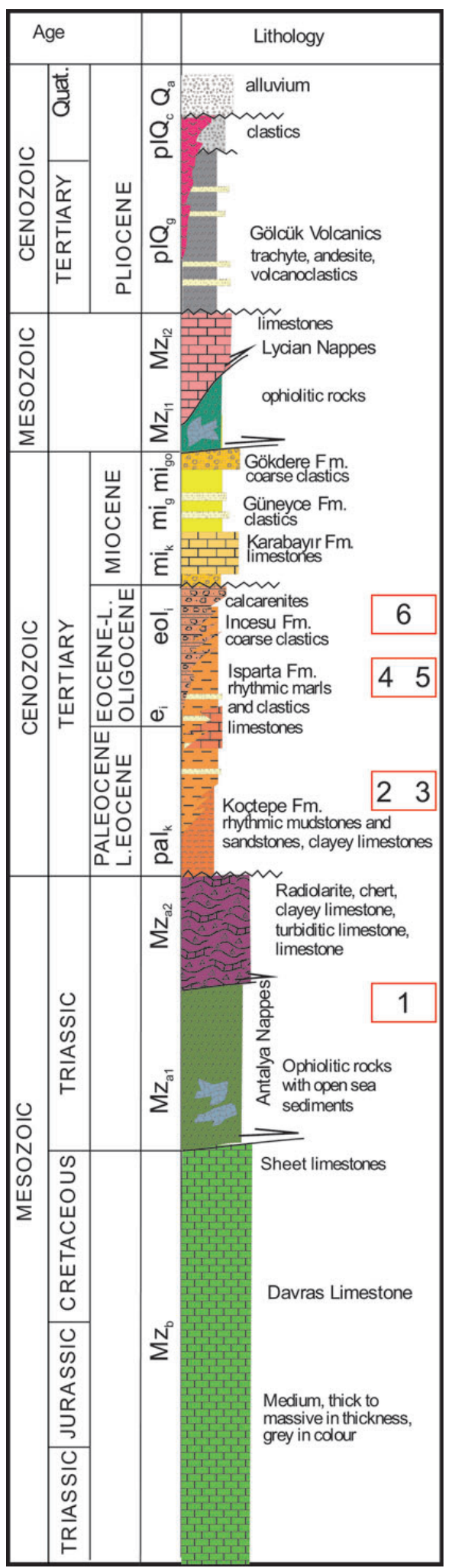

Figure 3. Generalised stratigraphical column showing sample levels (rectangle symbols) of trace fossils. 1 - Isparta Çay Formation, Ağilköy, 2 - Koçtepe Formation, Söbü I, 3 - Koçtepe Formation, Göltaș cement factory, 4 - Isparta Formation, Söbü II, 5 - Isparta Formation, Gökçebağ, 6 - Incesu Formation, Kale Tepe Gönen. 

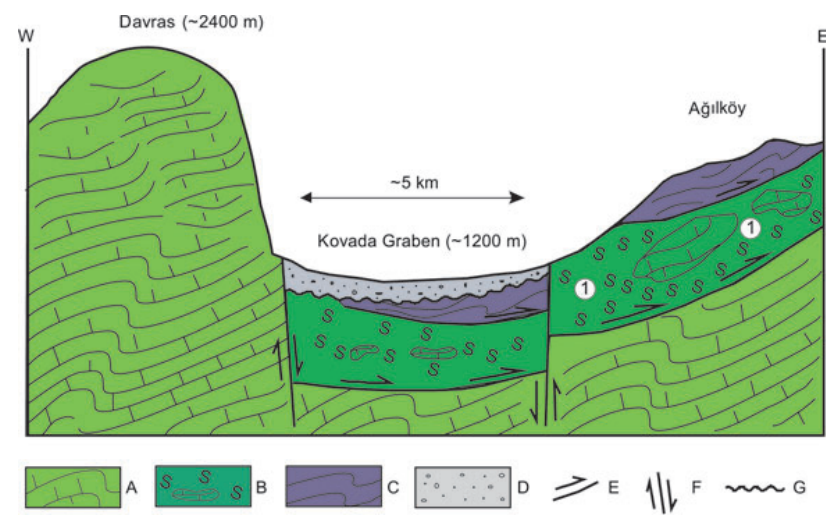

Figure 4. Schematic cross-section between Davraz and Ağilköy. A - Davraz Limestone, B - Ophiolitic Mélange in the Antalya Nappes, C - large blocks of Davraz Limestone in the Antalya Nappes, D - alluvium, $\mathrm{E}$ - thrust nappe, $\mathrm{F}$ - normal fault, $\mathrm{G}$ - discordance, 1 - locality 1 .

2003), including the Isparta Çay Formation and the Isparta Ophiolitic Mélange, which contain various Triassic to Early Cretaceous sediments (Fig. 4).

Isparta Çay Formation. - Deep-marine sediments of Triassic to Early Cretaceous age are associated with the Isparta Çay Formation, outcropping widely between the Savköy and Dereboğazı tunnels, and the surroundings of Ağılköy
(Eğirdir)-Kovada (Figs 2, 4). This unit was named the "Isparta Çay Unit" or "Isparta Çay Formation" in the literature (Dumont et al. 1972, Allasinaz et al. 1974, Poisson 1977, Gutnic et al. 1979, Yalçınkaya 1989). It comprises three members, i.e., radiolarite cherts, turbiditic limestone and sheet limestones (Yalçınkaya 1989). The Antalya nappes derive from the south (southern Neotethys and adjacent areas) and were emplaced during Late Cretaceous to Paleocene times (Gutnic et al. 1979, Görmüș et al. 2001b, Vrielynck et al. 2003). The Miocene Karabayır Formation covers unconformably the Isparta Çay Formation around the İmrezi village. The underlying units were not seen in the studied area. According to our field observations of different cross sections, the unit is more than $700 \mathrm{~m}$ thick. Various foraminifera, bivalves, ammonites and radiolaria were recorded. Foraminifera: Ammodiscus sp., Galeanella sp., Miliolipora sp., Nodosaria sp., Protopenoroplis striata, Reophax sp., Textularia sp., Trochammina sp., pseudocyclamines and trocholines. Radiolaria: Emiluvia sp., Cinguloturris carpatica, Leugeo hexacubicus, Parahsuum sp., Paronaella sp., P. cf. kotura, Parvicingula dhimenaensis, P.?spinata, P. sp., Podobursa sp., Transhuum maxwelli and Triactoma jonesi. Bivalvia: Halobia austriaca, H. halorica, H. charliana, H. lineate, H. striatica. Cephalopoda: Aulacoceras cf. sulcatum,

Table 1. Overview showing the stratigraphical distribution of trace fossils in the Triassic to early Cretaceous and Paleocene to Oligocene formations of the Eğirdir, Gönen and Isparta regions. Note: +, few specimens; ++, common; +++, abundant.

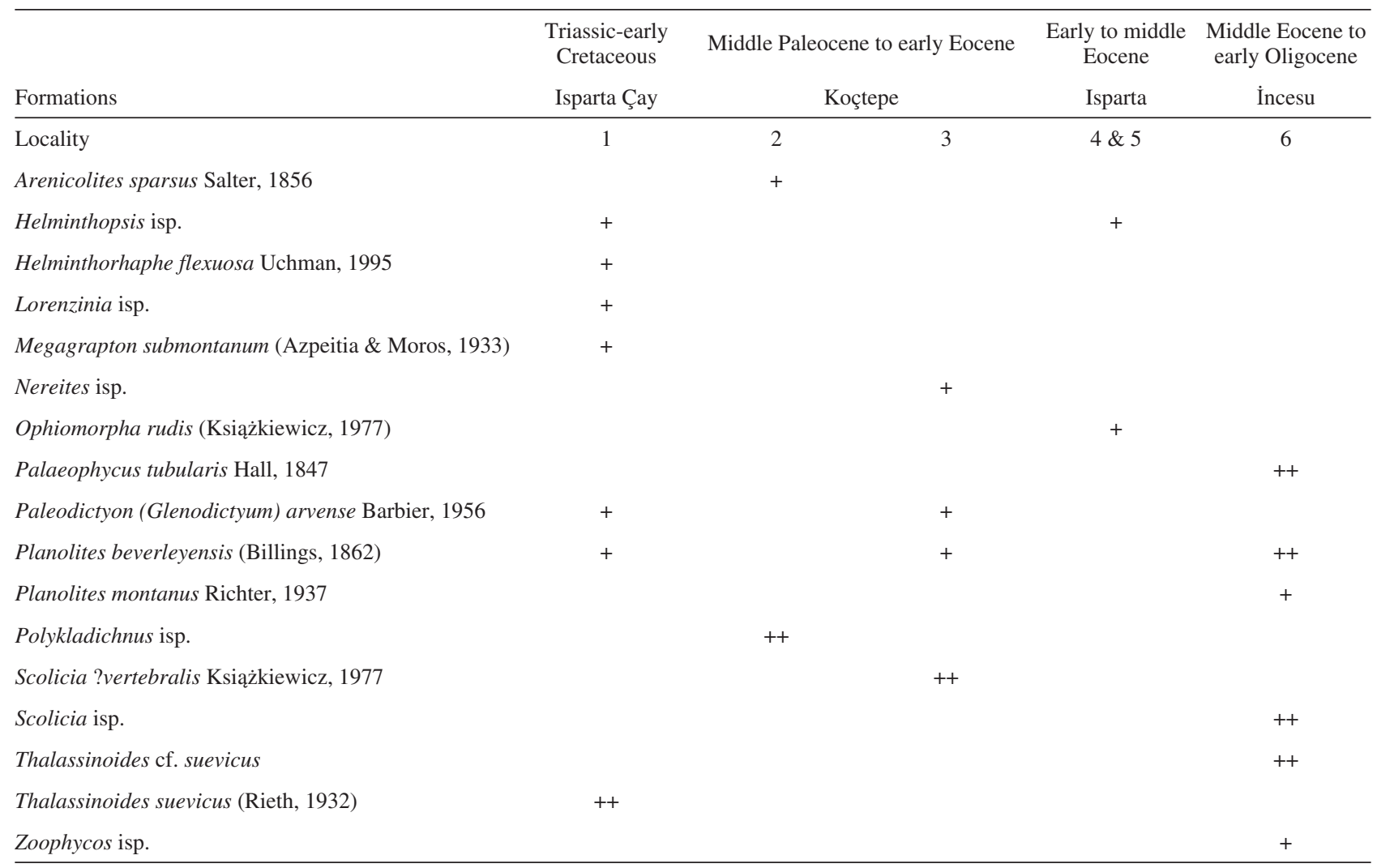



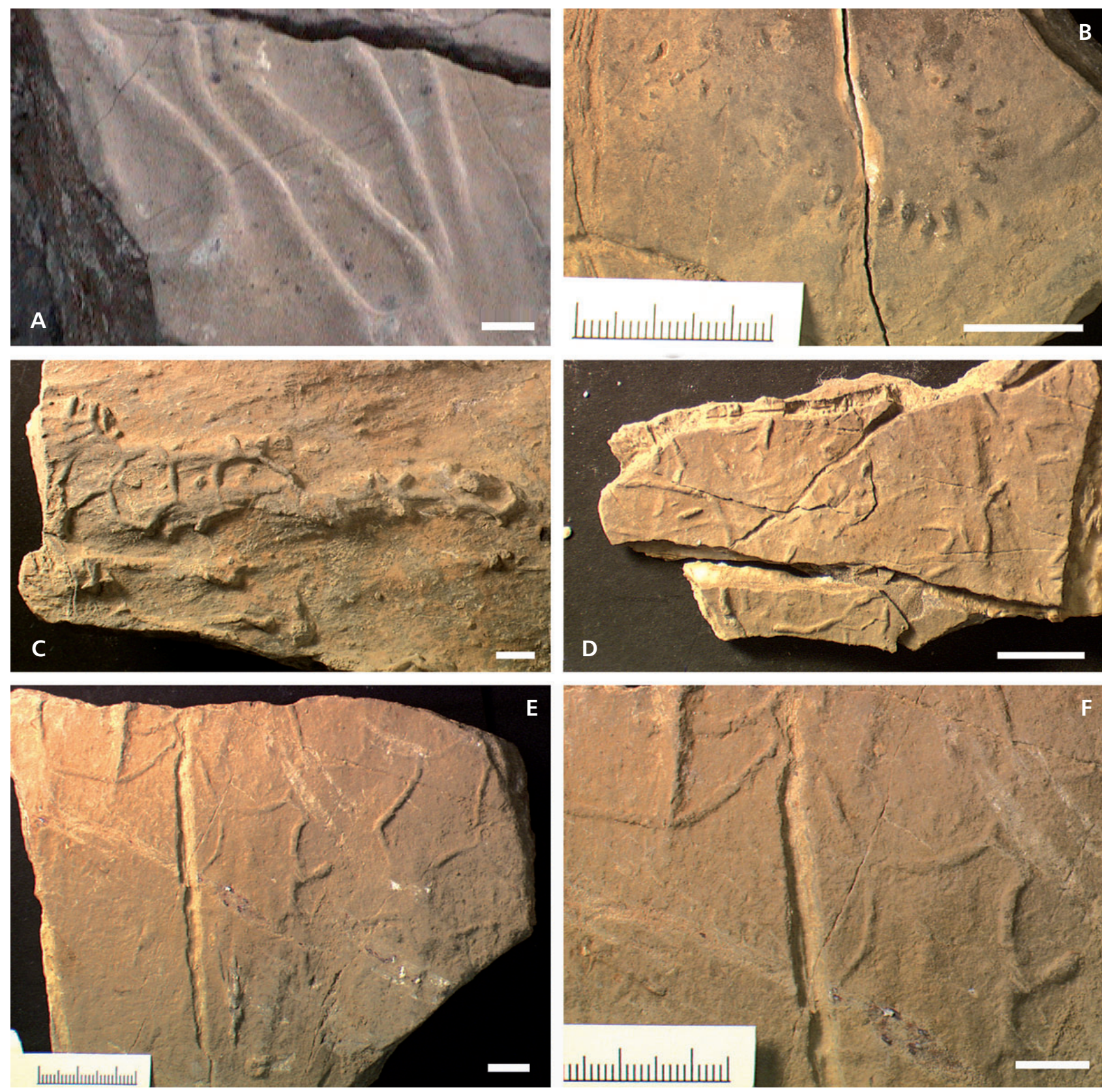

Figure 5. Trace fossils from the Isparta Çay Formation, locality 1.•A - Helminthorhaphe flexuosa, preserved in hyporelief. • B - Lorenzinia isp., hyporelief. $\bullet \mathrm{C}-$ Paleodictyon arvense, hyporelief. $・ \mathrm{D}-$ Helminthopsis isp., hyporelief. $\bullet \mathrm{E}, \mathrm{F}-$ Megagrapton submontanum, hyporelief. Scale bars: $1 \mathrm{~cm}$.

Aulacoceras sp., Clacidites sp., Juvatites sp. and Megaphyllites sp. (Yalçınkaya 1989, Tekin 1999, Vrielynck et al. 2003). According to the species of Halobia recoreded, a Late Triassic age can be assigned to the bottom part of the formation, whereas the middle and upper parts of the formation contain Jurassic to Early Cretaceous ammonites and radiolaria (Vrielynck et al. 2003). Lithological and faunal characteristics indicate a deeper palaeoenvironment for the Isparta Çay Formation with turbiditic currents.
Isparta Ophiolitic Mélange. - This geological unit contains ophiolitic rocks mixed with Triassic to Early Cretaceous sediments. It was named the Isparta Ophiolitic Complex by Yalçınkaya (1989). Here we prefer the suffix mélange instead of complex due to mixing of both sediments and ophiolites. They are exposed in the areas around Darıoren, Savköy, Ağılköy and Kovada. Trace fossils occur within the sedimentary blocks of the mélange, which derived from the Isparta Çay Formation and other Triassic to Cretaceous carbonates. 


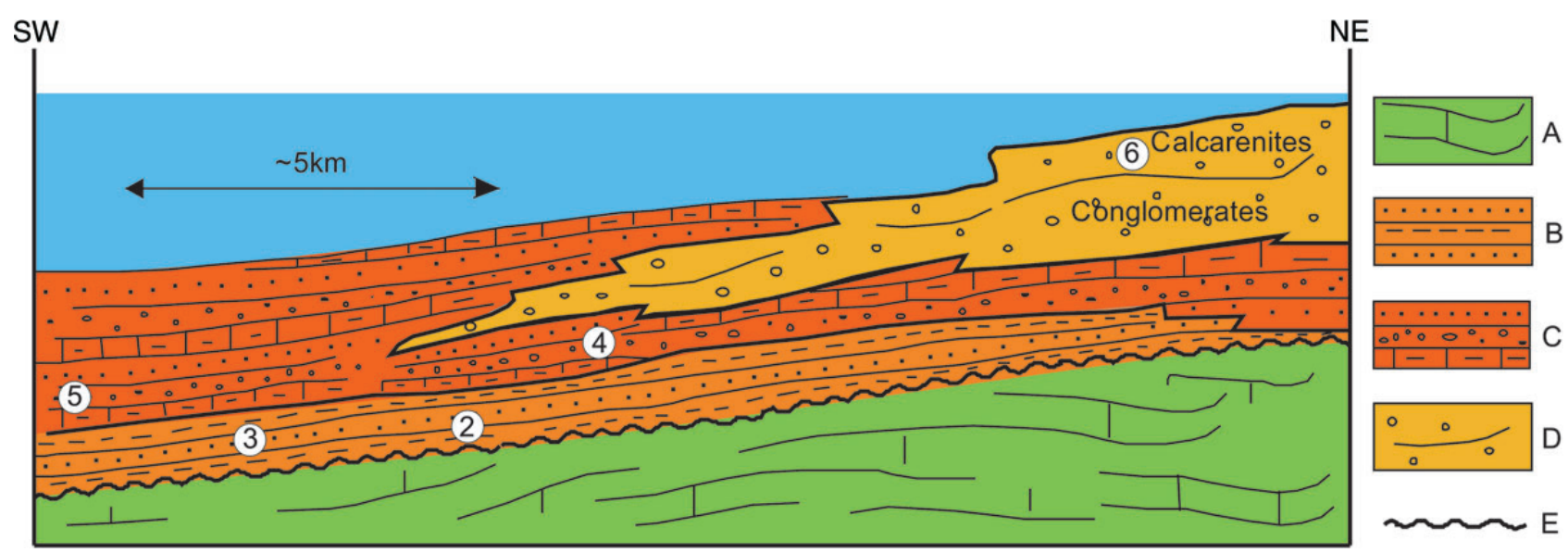

Figure 6. Palaeoenvironmental reconstruction of Paleocene to Early Oligocene successions. • A - Davraz Limestone, B - Koçtepe Formation, C - Isparta Formation, D - İncesu Formation, E - disconformity, 2-6-localities.

Ichnological observations. - The Isparta Çay Formation, which is poorly exposed at Ağ1lköy (locality 1), has a low density and moderate diversity of trace fossils (Table 1; Fig. 5). Cross-cutting relationships between them were not found.

Thalassinoides suevicus is preserved in full relief and displays mainly horizontally orientated galleries, which are approximately $2 \mathrm{~cm}$ wide and their margin is smooth. Thalassinoides suevicus formed as branched burrow systems parallel to the bedding, with enlargement at junctions between some branches. These junctions are Y- or $\mathrm{T}$-shaped and show a branching angle up to $70^{\circ}$. The probable trace maker was an arthropod.

Planolites beverleyensis occurs as simple horizontal or oblique cylindrical burrows, less than $1 \mathrm{~mm}$ wide, without walls or internal structures, circular to oval in transverse cross-sections. They are preserved in full relief.

Lorenzinia isp. consists of up to twenty radially arranged, separated hypichnial ridges, which are up to $5 \mathrm{~mm}$ long (Fig. 5B). The diameter of the entire trace fossil is about $26 \mathrm{~mm}$. The number of preserved ridges is partly controlled by sedimentary erosion.

Paleodictyon (Glenodictyum) arvense occurs as a convex hyporelief on the underside of erosive turbiditic sandstones (Fig. 5C). The networks resemble a honeycomb pattern, with a lateral extent of at least $12.8 \mathrm{~cm}$. The strand diameter is approximately $2 \mathrm{~mm}$. Maximum mesh size is $21 \mathrm{~mm}$. These measurements are within the morphometric range of $P$. (Glenodictyum) arvense as defined by Uchman (1995).

Megagrapton submontanum occurs rarely in the Isparta Çay Formation (Fig. 5E, F). The network consists of irregularly shaped meshes. The mesh size appears to be up to $43 \mathrm{~mm}$. The winding strands are $2 \mathrm{~mm}$ wide. The branching angle may be acute. Megagrapton submontanum was revised by Uchman (1998) and is distinguished from $M$. irregulare by its winding strings and the branching angle.
Helminthorhaphe flexuosa is a hypichnial unbranched, smooth, regularly meandering semicircular ridge (Fig. 5A). The ridge is 3 to $4 \mathrm{~mm}$ wide and forms one-order meanders, which are irregular and poorly defined in outline. Helminthorhaphe flexuosa differs from H. japonica, which has densely defined meanders with high amplitude and bulging turns (Uchman 1998).

Helminthopsis isp. displays an unbranched, hypichnial ridge showing an irregularly winding course (Fig. 5D). The ridge is unlined and semicircular in cross-section. The width is $2 \mathrm{~mm}$ and the ridge can be traced to a distance of at least $12 \mathrm{~cm}$.

\section{Paleocene to Early Oligocene}

The Paleocene to Eocene formations are from bottom to top as follows: Koçtepe Formation, Isparta Formation and İncesu Formation (Fig. 6). The Isparta Formation includes rhythmic clastics (succession I), carbonates (succession II) and calcarenites (succession III). The İncesu Formation contains medium to coarse-grained clastics (succession I) and calcarenites (succession II).

Koçtepe Formation. - It was named after Koçtepe village near to the Süleyman Demirel University Campus by Sariiz (1985). The Kizılkırma Formation from the Söbüdağ area and Kabaktepe Formation from the Savköy area are thought to be synonyms for the Koçtepe Formation (Koçyiğit 1984, Karaman et al. 1988, Yalçınkaya 1989). The Koçtepe Formation consists of a succession of interbedded reddish mudstones and yellowish sandstones of siliciclastic composition. The thin to medium bedded sandstones, which are generally fine-grained and moderately sorted, may be structureless or contain small-scale cross-bedding. The succession is around $50 \mathrm{~m}$ thick. The Koçtepe Formation is underlain by sheet limestones of the 

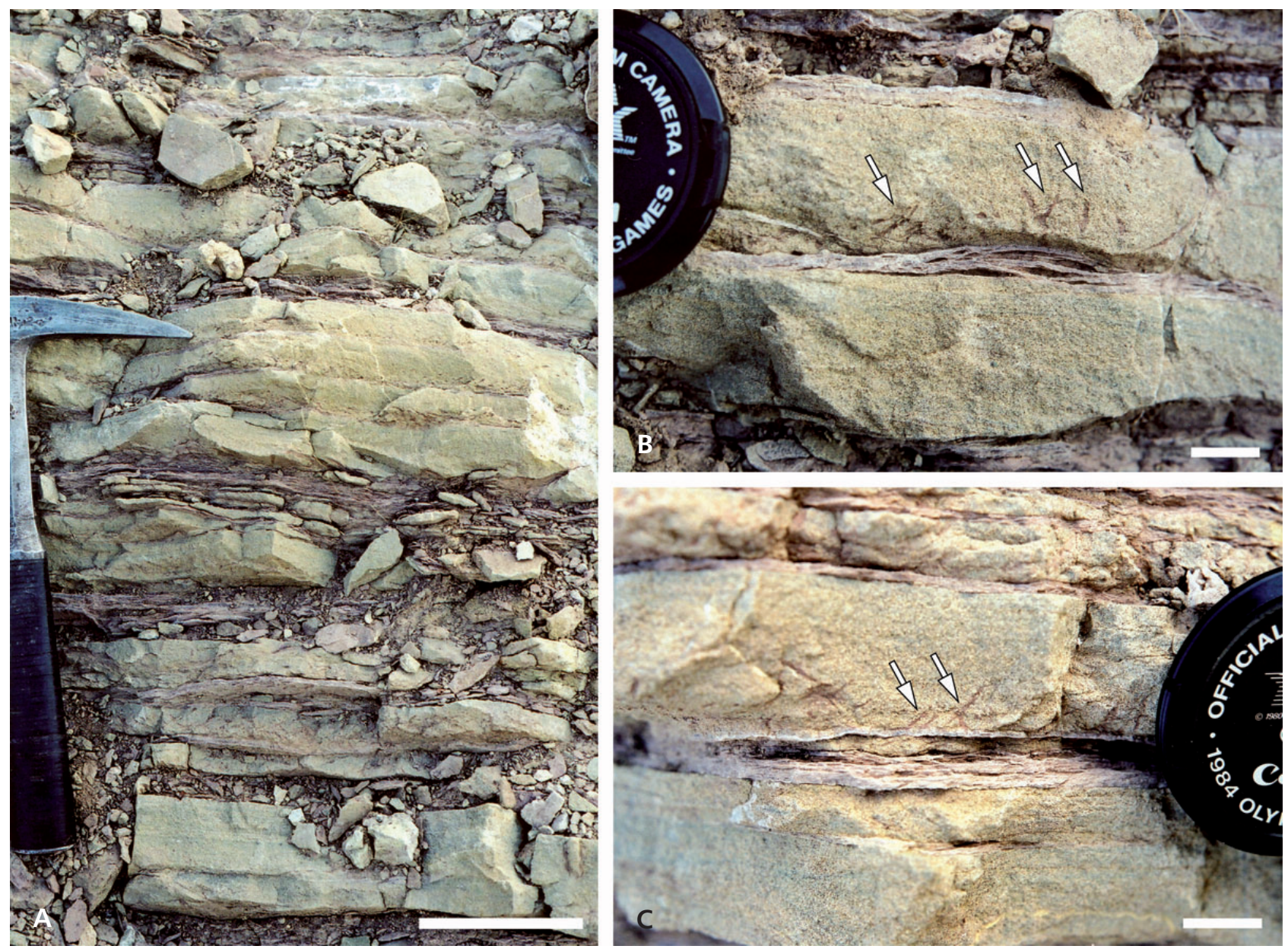

Figure 7. A - overturned heterolithic beds of the Koçtepe Formation, locality 2 (Söbü I ). B, C-examples of overturned Polykladichnus isp. (arrows). Scale bars: $\mathrm{A}=10 \mathrm{~cm} ; \mathrm{B}, \mathrm{C}=1 \mathrm{~cm}$.

Campanian to Maastrichtian Çiğtemtepe limestone, and overlain by the Isparta Formation clastics. The transition between the Koçtepe and Isparta formations is gradual in facies. The mudstones contain a rich content of planktonic foraminifera but fewer benthic foraminifera: Acarinina primitive, A. sp., Globigerina linaperta, G. triangularis, G. triloculinoides, G. trivalis, G. veloscoensis, Morozovella angulata, M. aragonensis, M. conicotruncata, M. formasa formasa, M. quetra, M. sp., Planorotalites chapmani, $P$. cf. pusilla pusilla and $P$. sp. Benthic foraminifera: Ammodiscus sp., Anomolina sp., Bulimina sp., Cibicides sp., Clavulinoides sp., Dorothia sp., Ellipsonodosaria sp., Gaudryina sp., Guttulina sp., Gyroidina sp. Haplophragmoides sp., Neoflabellina sp., Oolina sp., Robulus sp., Textularia sp. and Verneuilina sp. (Görmüș \& Karaman 1992). Within the sandstones, reworked Cretaceous planktonic and benthic foraminifera are common including taxa such as Alveolina sp., Discocyclina sp., Nummulites sp. and Sphaerogypsina globules. An alga, Dictichoplax biserialis, was also recorded in the sandstones. The foraminifers point to a middle Paleocene-Early
Eocene age for the Koçtepe Formation. Faunal contents indicate a middle to outer shelf palaeoenvironment.

Ichnological observations. - In the Koçtepe Formation, two different trace fossil assemblages were recognized (Table 1; Figs 7, 8). At the road section (locality 2, Söbu I), the assemblage is characterized by low diversity and density of trace fossils.

Arenicolites sparsus is a vertical U-shaped burrow without spreite, filled with reddish fine-grained sediment. The trace fossil is up to $15 \mathrm{~mm}$ tall. The limbs are unlined and smooth, $10 \mathrm{~mm}$ apart and $2 \mathrm{~mm}$ in diameter. The limbs diverge upwards. Based on these characteristics, the specimens are assigned to Arenicolites sparsus (see Salter 1857, Rindsberg \& Kopaska-Merkel 2005).

Polykladichnus isp. is a vertical shaft having upward-directed Y shaped branching (see Fürsich 1981, Schlirf \& Uchman 2005). This trace fossil is $30 \mathrm{~mm}$ long and $10 \mathrm{~mm}$ wide. The shaft and branches are smooth, unlined and $1 \mathrm{~mm}$ in diameter. They are filled with the overlying muddy sediment. Notably the trace fossils differ from 

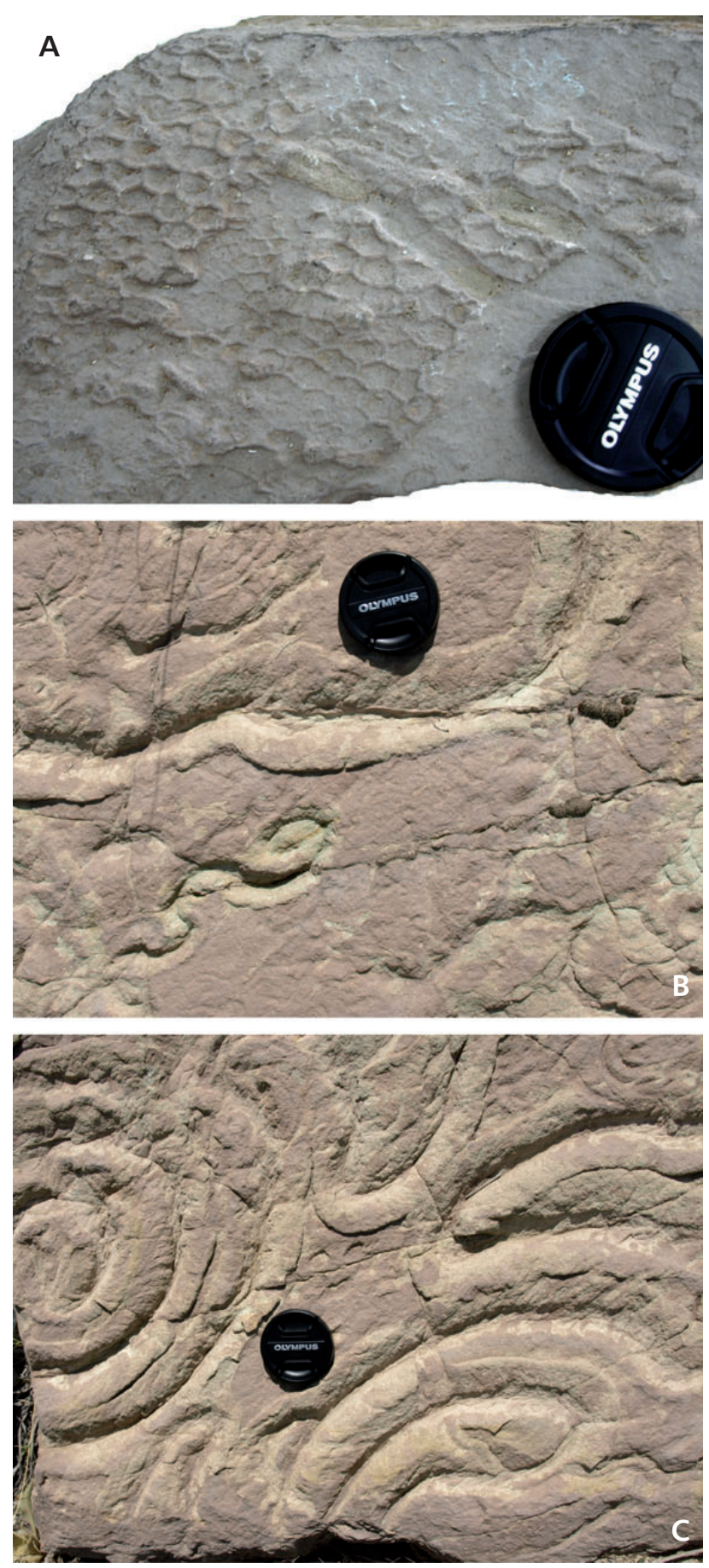

Figure 8. Trace fossils from the Koçtepe Formation, Göltaș cement factory, locality 3 . $\bullet \mathrm{A}-$ Paleodictyon (Glenodictyum) arvense. $\bullet \mathrm{B}, \mathrm{C}-\mathrm{Sco}$ licia ?vertebralis. Lens cap: $6 \mathrm{~cm}$ in diameter.

Polykladichnus irregularis by the lack of wall lining. The ichnogenus Polykladichnus is defined by its burrow pattern of mainly vertical tubes with Y-bifurcations (Fürsich 1981). The branching pattern is a significant ichnotaxobase in simple, vertical structures, whereas the presence or ab- sence of wall lining may be used for ichnospecific differentiation (Schlirf \& Uchman 2005).

The succession in a nearby road section consists of similar deposits as at locality 2. Notably the deposits have been tectonically overturned as indicated by the upside down trace fossils of Polykladichnus isp. (Fig. 7). This is in accordance with structural indicators such as orientation of the folded succession in the area.

The Koçtepe Formation which is exposed at the Göltaș cement factory (locality 3 ) contains a different trace fossil assemblage. The under surfaces of the sandstone beds may contain Scolicia ?vertebralis, Planolites beverleyensis, Paleodictyon (Glenodictyum) arvense and Nereites isp. (Fig. 8).

Scolicia ?vertebralis has a winding course and displays remnants of meniscate backfill (Fig. 8B, C). A narrow central groove and one strand along its base are present. The width of the entire trace fossil is about $7 \mathrm{~cm}$. There is incomplete diagnostic evidence for specific determination. In addition, Scolicia vertebralis is possibly a preservational variant of $S$. prisca and, therefore, its status is unclarified (Uchman 1998).

Paleodictyon (Glenodictyum) arvense is a convex hyporelief regular network, which resembles a honeycomb pattern (Fig. 8A). Individual strands are up to $7.5 \mathrm{~mm}$ long. The strand width is about $2 \mathrm{~mm}$. Maximum mesh size is $16.5 \mathrm{~mm}$. The morphometric range defines the specific identification (Uchman 1995).

Planolites beverleyensis is an unlined hypichnial cylinder, 7-12 mm wide, traced over a distance of $12 \mathrm{~cm}$.

Isparta Formation. - At first it was called Isparta flysch by Gutnic et al. (1979) and is widely exposed between the cities of Isparta and Burdur. Around Isparta city, the Kayıköy Formation from the Söbüdağ area and Savköy Formation from the Savköy area are thought to be synonyms for the Isparta Formation (Karaman et al. 1988, Yalçınkaya 1989). Yalçınkaya (1989) described the Kurttepe Formation from the Eocene of the Ağlasun area. It is also a synonym for the Isparta Formation. Sariiz (1985) uses the name Isparta Formation. We prefer this name due to different accumulation of the sediments, such as carbonate-dominated sediments and siliciclastic dominated sediments, during the Late Paleocene to Eocene. In addition, the formation was formed in shallow-marine to open-marine palaeoenvironments. Thus, the Isparta Formation may be separated into different successions such as rhythmic clastics and marls (succession I), carbonates (succession II) and calcarenites (succession III). Rhythmic clastics and marls are seen around Kayıköy and Mensucat, and at the Göltaş cement factory. Carbonates crop out around the Savköy area, and the third succession crops out on the Kayisivrisi Hill near to Kayıköy village. The third succession was distinguished by Yeşilot (2000) as the Kayısivrisi Member. The thickness of the Isparta Formation is more than $700 \mathrm{~m}$. It 
Figure 9. The Isparta Formation at locality 4 . $\bullet$ A - normal graded beds with erosive bases. $\bullet \mathrm{B}-$ Ophiomorpha rudis, full relief. - C - Helminthopsis isp., hyporelief. Lens cap: $5.5 \mathrm{~cm}$ in diameter. Scale bar: $5 \mathrm{~cm}$.
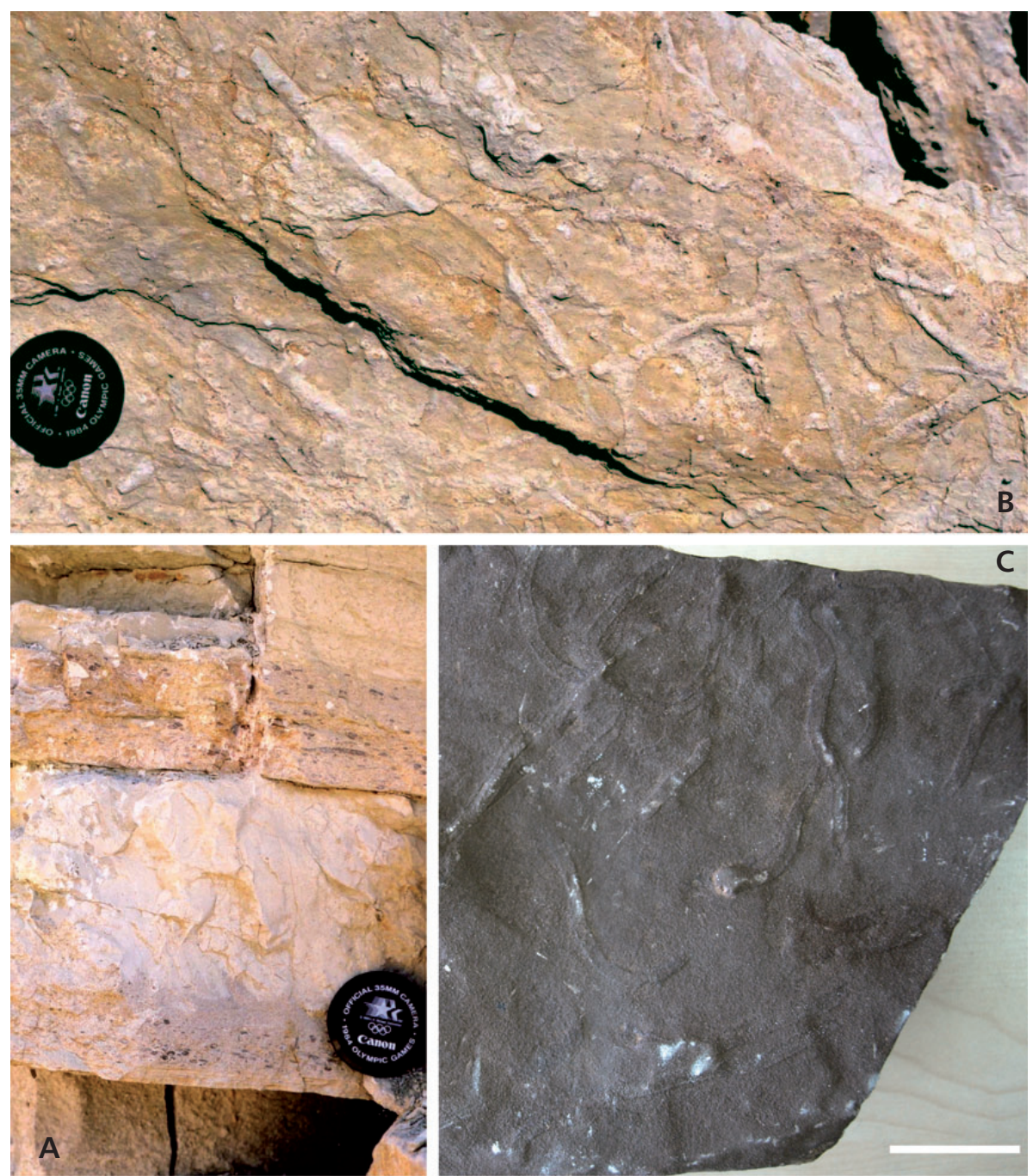

has vertical and lateral facies underlain by the Koçtepe Formation and overlain by the İncesu Formation. Akkiraz et al. (2007) suggested an unconformity between the Isparta Formation and İncesu Formation; however, we consider it as facies transition. The facies changes are clearly observable around the Gönen and İğdecik areas. The faunal content can be summarised as follows: Planktonic foraminifera: Acarinina broedermanni, A. bullbrooki, Globigerina linaperta, G. senni, G. turgida, G. yeguaensis, Globigerinoides higginsis, Morozovella aragonensis, M. caucasica, M. crassata, M. gracilis, M. cf. lehneri, M. cf. quetra, M. spinulosa, M. subbotina, Turborotalia centralis and Truncorotaloides rohri. Benthic foraminifera: Alveolina sp., Amphistegina sp., Dictyoconus sp., Discocyclina sp., Elphidium sp., Europertia magna, Fabiania cassis, Gypsina sp., Nummulites aturicus, N. beaumonti, N. millecaput, N. perfaratus, N. sp., Operculina sp., Peneroplis sp., Rotalia sp., Silvestriella tetraedra, Sphaerogypsina globula and Textularia sp. (Karaman 1994, Görmüș \& Özkul 1995). Reworked Cretaceous planktonic and benthic fora- minifera and Dictichoplax biserialis, an alga. Synsedimentary nannofossils: Braarudosphaera bigelowii, Chiasmolithus californicus, C. consuetus, C. grandis, Cooccolithus pelagicus, Discoaster barbadiensis, D. binodosus, D. deflandrei, D. diastypus, D. gemmifer, D. kuepperi, D. lodoensis, D. salisburgensis, D. scrippsae, Ericsonia cava, E. formosa, E. ovalis, Lophodolithus nascens, Reticulofenestra dictyoda, Sphenolithus conspicuous, S. editus, S. moriformis, S. radians, Toweius crassus, T. gammation, T. occultatus, T. pertusus, Tribrachiatus orthostylus and Zygrhablithus bijugatus. Reworked nannofossils from the Cretaceous to Early Paleocene: Arkhangelskiella cymbiformis, Aspidolithus parcus constrictus, Biantolithus sparsus, Cribrosphaerella ehrenbergii, Cruciplacolithus primus, Cyclagelosphaera reinhardtii, Eifellithus eximius, E. turriseiffelii, Fasciculithus involutus, F. tympaniformis, Lithraphidites quadratus, Microrhabdulus attenuatus, Micula decussata M. murus, Nannoconus sp., Placozygus fubiliformis, Prinsius dimorphosus, P. bisulcus, Rhabdolekiskus parallelus, Stradneria crenulata, 
Thoracosphaera operculata and Watznaueria barnesae (Sagular \& Görmüș 2006). The fossils indicate an Early to Middle Eocene age for the Isparta Formation. Lithological characteristics and fossil content indicate an open-marine palaeoenvironment.

Ichnological observations. - At localities 4 (Söbü II) and 5 (Gökçebağ), the Isparta Formation is comprised of rhythmic successions of marls, sandstones and conglomeratic sandstones. The ichnodensity is low (Table 1, Fig. 9). There are a few specimens of Helminthopsis isp. and Ophiomorpha rudis.

Helminthopsis isp. is a semicircular hypichnial ridge on the underside of the sandstone beds (Fig. 9C). The ridge is unbranched and about $3 \mathrm{~mm}$ wide. Helminthopsis isp. is recognized by its irregularly winding course.

Ophiomorpha rudis is a three-dimensional cylindrical burrow system, which contains horizontal to oblique, straight to slightly curved branched elements, all preserved in full relief (Fig. 9B). The branching angle ranges from 60 to $90^{\circ}$. The burrow diameter is about $14 \mathrm{~mm}$. The distance between branches may reach $34 \mathrm{~cm}$. Wall lining is weakly developed and occurs along the branch roof and at the branching points. The branching points may be slightly swollen.

Incesu Formation. - It was called the İncesu conglomerates after the village of İncesu near to Keçiborlu town in the city of Isparta by Gutnic et al. (1979). Koçyiğit (1984) named it the İncesu Formation, based on outcrops from the Senirkent area. We prefer the second alternative due to occurrences of various clastic deposits in the formation. The İncesu Formation crops out widely around Gönen, İğdecik and Gümüşgün. The formation is composed of sandstones, conglomerates and calcarenites. The calcarenites mainly occur in the uppermost part of the sedimentary succession, e.g. at Gönen Kale Hill. They were assigned by Akkiraz et al. (2007) to the Delikarkas1 Formation. The İncesu Formation may be subdivided into different units. However, we accept them as different successions of the same formation and divide them only into succession I (medium- to coarse-grained clastics) and succession II (calcarenites) due to insufficient documentation. The thickness of the İncesu Formation is around $600 \mathrm{~m}$. The formation has vertical and lateral facies transitions with the underlain Isparta Formation. The faunal content of both succession I and II of this formation are as follows: Alveolina sp., Assilina sp., Asterigerina sp., Discocyclina sp., Europertia sp., Fabiania sp., Gypsina sp., Halkyardia sp., Opertorbitolites sp., Nummulites aturicus, $N$. perfaratus and Silvestriella tetraedra. Akkiraz et al. (2007) recorded the following faunal content from the calcarenites of the formation: Nummulites intermedius, N. vascus, Lepidocyclina sp. (foraminifera), Boehlensipollis hohli, Dicolpopollis kockelii, Intratriporopollenites instructus, Leiotriletes maxoides ssp., Pediastrum spp., Pli- capollis pseudoexcelsus, Polypodiaceoisporites sp., Slowakipollis hippophaëoides, Subtriporopollenites simplex, Triatriopollenites excelsus, Verrucatosporites sp. and dinoflagellate cysts (palynomorphs). The previous records indicated a Middle Eocene to Early Oligocene age. Lithological characteristics and faunal content indicate a shallower marine palaeoenvironment. Akkiraz et al. (2007) also discussed marine and land influences, and palaeoclimatological aspects based on the aforementioned fossils and tree plant fossils ascribed to Castanea, Pinus, Cathaya, Abies and Podocarpus.

Ichnological observations. - The Middle Eocene to Early Oligocene İncesu Formation overlies and is laterally equivalent to the Isparta Formation. The İncesu Formation is exposed at Gönen Kale Hill (locality 6) and consists of whitish to yellowish calcarenites of packstone and grainstone with bioclasts. The calcarenites, which are up to $50 \mathrm{~cm}$ thick, may be structureless, parallel bedded or weakly cross bedded. The sediment may be normal graded. There are only a few ophiolitic clasts. A-form Nummulites may be common and occur parallel to bedding where the sediment is unbioturbated. Stratification surfaces represent times of non-deposition or erosion and are moderately bioturbated.

The ichnodiversity is moderate to high at Gönen Kale Hill (Table 1, Fig. 10). Thalassinoides cf. suevicus, Planolites beverleyensis and Scolicia isp. are common. Zoophycos isp. is rare. Overall the density of trace fossils is moderate.

Thalassinoides $\mathrm{cf}$. suevicus displays straight to gently curved Y-shaped branches (Fig. 10C, D). The individual branches are up to $40 \mathrm{~cm}$ long and about $0.5-2 \mathrm{~cm}$ in diameter. The branching angle ranges from 30 to $80^{\circ}$. The burrow fill is structureless and consists of calcareous sand. In some specimens, the fill contains numerous benthic foraminiferal tests.

Planolites beverleyensis is a cylindrical burrow about $2-5 \mathrm{~mm}$ in diameter (Fig. 10B, E). The fill is structureless and appears to be slightly more fine-grained than the surrounding sediment in lithology.

Scolicia isp. as the preservational variant Laminites is common and occurs parallel to the bedding. The trace fossil consists of biserial meniscate backfill in which only the upper part is visible (Fig. 10A-C). This preservational variant lacks further diagnostic features (Uchman 1995). The diameter of the backfill is $0.8 \mathrm{~cm}$. The length may be at least $50 \mathrm{~cm}$. The backfill is of sediment lithologically similar to the adjacent substrate.

Palaeophycus tubularis occurs as straight to gently curved, rarely branched, predominantly horizontal to oblique tubular burrows with thin wall lining of fine-grained sediment (Fig. 10A, B, F). They are circular to slightly elliptical in cross-section and uncommonly show secondary successive branching. The branching angle is 

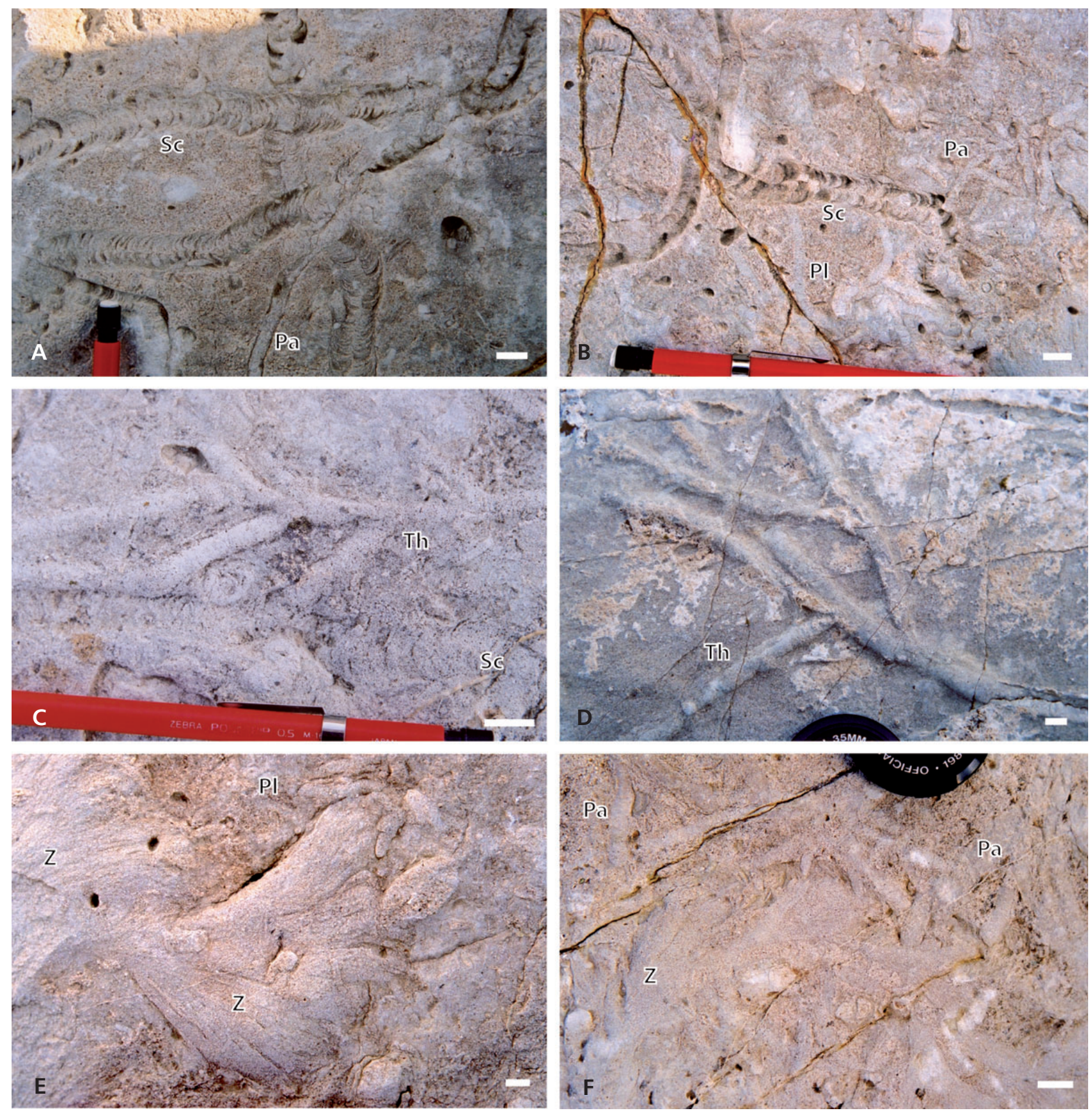

Figure 10. Trace fossils from the İncesu Formation at locality 6. - A - Scolicia isp. (Sc) and Palaeophycus tubularis (Pa). B - Scolicia isp., Palaeophycus tubularis and Planolites beverleyensis $(\mathrm{Pl}) \cdot \bullet \mathrm{C}-$ Thalassinoides $\mathrm{cf}$. suevicus $(\mathrm{Th})$ cross-cut by Scolicia isp. $\bullet \mathrm{D}-$ Thalassinoides $\mathrm{cf}$. suevicus. $\bullet$ E - Zoophycos isp. cross-cutting Planolites beverleyensis. $\bullet \mathrm{F}-$ Zoophycos isp. and Palaeophycus tubularis. The trace fossils are preserved in full relief. Scale bars: $1 \mathrm{~cm}$.

acute. The diameter is up to $8 \mathrm{~mm}$. The filling is structureless and of the same lithology as the surrounding sandy sediment. The trace fossil is preserved as full reliefs.

Zoophycos isp. are fan-shaped spreite structures. The fan angle is about 30 to $85^{\circ}$ and up to $7 \mathrm{~cm}$ wide (Fig. 10E, F). The length of individual fans is approximately $5-6 \mathrm{~cm}$. The largest fan is $19 \mathrm{~cm}$ long and $10 \mathrm{~cm}$ wide. This fan structure is intersected by a single burrow with meniscate backfill resembling Taenidium isp. The latter is $5 \mathrm{~mm}$ in diameter and contains a coarser fill compared with the fan structure. The filling of the fan structures resembles the surrounding sandy sediment; subtle variation in grain size enhances the internal structures. The fans are located parallel to the bedding. 
Table 2. Previous ichnological investigations in Turkey and their findings of trace fossil assemblages for comparison with the present study. A - Y1ldiz et al. (2000; Kalecik, ANKARA), B - Sevim (2003; Göynük-Taraklı, ADAPAZARI), C - Özkul (1993; ELAZIĞ), D - Doğdu (2007; Haymana, ANKARA), E - Demircan (2008; Saros Körfezi KD’su Yenimuhacir-Keşan-Korudağ), F - Uchmann \& Demircan (1999a; Karaisal1-Eymirler, Çatalhan-Eylence River, ADANA), G - Uchmann \& Demircan (1999b; Kalaycılar-Çorlu-Hacımusalı, ADANA), H - Uchman et al. (2002; Dağpazarı-Kavaközü, MUT), I - Demircan \& Toker (2003; Karaisal1-Çatalan-Eğner, ADANA), J - Demircan \& Toker (2004; Karaisal1-Çatalan-Eğner, ADANA), K - Yıldız et al. (2003; Hacıahmetli-Sarıkavak-Kargıcak, MUT), P-P - Plio-Pleistocene

\begin{tabular}{|c|c|c|c|c|c|c|c|c|c|c|c|}
\hline & \multicolumn{2}{|c|}{$\begin{array}{l}\text { Cretaceous- } \\
\text { Paleocene }\end{array}$} & \multicolumn{3}{|c|}{$\begin{array}{l}\text { Paleocene- } \\
\text { Eocene }\end{array}$} & \multicolumn{5}{|c|}{ Miocene } & \multirow{2}{*}{$\begin{array}{c}\text { P-P } \\
\text { K }\end{array}$} \\
\hline & A & B & $\mathrm{C}$ & $\mathrm{D}$ & E & $\mathrm{F}$ & $\mathrm{G}$ & $\mathrm{H}$ & I & $\mathrm{J}$ & \\
\hline Arthrophycus tenuis (Książkiewicz, 1977) & & & & & & & & & & $?$ & \\
\hline Arthrophycus cf. tenuis (Książkiewicz, 1977) & & & & & & $\bullet$ & & & & & \\
\hline Asterichnus isp. & & & $\bullet$ & & & & & & & & \\
\hline Belorhaphe tebteqae Azpeitia, 1933 & & & - & & & & & & & & \\
\hline Capodistria vettersi Vialov, 1968 & & & & & & & & & $\bullet$ & & \\
\hline Caulostrepsis taeniola Clarke, 1908 & & & & & & & & $\bullet$ & & & \\
\hline Chondrites affinis (Brongniart, 1828) & & & $\bullet$ & & & & & & & & \\
\hline Chondrites intricatus (Brongniart, 1823) & & & & & & • & & & & & \\
\hline Chondrites isp. & & • & & $\bullet$ & $\bullet$ & & - & & $\bullet$ & & - \\
\hline Conchotrema? isp. & & & & & & & & $\bullet$ & & & \\
\hline Cosmorhaphe sinuosa (Azpeitia \& Moros, 1933) & & & & & $\bullet$ & $\bullet$ & & & $\bullet$ & $\bullet$ & \\
\hline ?Cosmorhaphe isp. & & & & & & $\bullet$ & & & & & \\
\hline Curvolithus simplex Buatois et al., 1998 & & • & & & & & & & & & \\
\hline Desmograpton dertonensis (Sacco, 1888) & & & & & & & & & & $\bullet$ & \\
\hline Desmograpton ichthyforme (Macostay, 1967) & & & & & & $\bullet$ & & & & $\bullet$ & \\
\hline Desmograpton isp. & & & & & & & & & & $\bullet$ & \\
\hline Echinospira Girotti, 1970 & & & & & & - & - & & • & & \\
\hline Entobia cf. goniodes Bromley \& Asgaard, 1993a & & & & & & & & $\bullet$ & & & \\
\hline Entobia laquea Bromley \& D’Alessandro, 1984 & & & & & & & & $\bullet$ & & & \\
\hline Entobia cf. ovula Bromley \& D’Alessandro, 1984 & & & & & & & & - & & & \\
\hline Entobia cf. solaris Mikuláš, 1992 & & & & & & & & $\bullet$ & & & \\
\hline Gastrochaenolites isp. & & & & & & & & - & & & \\
\hline Gastrochaenolites lapidicus Kelly \& Bromley, 1984 & & & & & & & & $\bullet$ & & & \\
\hline Gastrochaenolites torpedo Kelly \& Bromley, 1984 & & & & & & & & • & & & \\
\hline Ghondrites isp. & & & & & & & & & & & - \\
\hline Glockeria isp. & & & $\bullet$ & & & & & & & & \\
\hline Gordia isp. & & & - & & & & & & & & \\
\hline Gyrolithes isp. & & & & & & & & & & & $\bullet$ \\
\hline Halmenidium orivanse & & - & & & & & & & & & \\
\hline Halopoa annulata (Książkiewicz, 1977) & & - & & $\bullet$ & $\bullet$ & & & & & $?$ & \\
\hline Helicolithus tortuosus (Książkiewicz, 1970) & & & & & & & & & & $\bullet$ & \\
\hline Helminthoida crassa (Schafhäutl, 1851) & & & - & & & & & & & & \\
\hline Helminthoidichnites isp. & & & & & • & & & & & & \\
\hline Helminthopsis Heer, 1877 & - & & & & • & & & & $\bullet$ & - & \\
\hline Helminthorhaphe flexuosa Uchman, 1995 & & & & & & $\bullet$ & & & & - & \\
\hline Lockeia isp. & & & & & - & & & & & & \\
\hline Lophoctenium isp. & & & & & & & & & & $\bullet$ & \\
\hline Lorenzinia pustulosa (Książkiewicz, 1977) & & & & & & & & & $\bullet$ & & \\
\hline Meandropolydora isp. & & & & & & & & - & & & \\
\hline ?Megagrapton isp. & & & & & & & & & & • & \\
\hline
\end{tabular}


Table 2 - continued

\begin{tabular}{|c|c|c|c|c|c|c|c|c|c|c|c|}
\hline & \multicolumn{2}{|c|}{$\begin{array}{l}\text { Cretaceous- } \\
\text { Paleocene }\end{array}$} & \multicolumn{3}{|c|}{$\begin{array}{l}\text { Paleocene- } \\
\text { Eocene }\end{array}$} & \multicolumn{5}{|c|}{ Miocene } & \multirow{2}{*}{$\begin{array}{c}\text { P-P } \\
\text { K }\end{array}$} \\
\hline & A & B & $\mathrm{C}$ & D & E & $\mathrm{F}$ & $\mathrm{G}$ & $\mathrm{H}$ & I & $\mathrm{J}$ & \\
\hline Neonereites uniserialis Seilacher, 1960 & & & - & & & & & & & & \\
\hline Nereites irregularis (Schafhäutl, 1851) & & & & & $\bullet$ & $\bullet$ & & & & $\bullet$ & \\
\hline Ophiomorpha annulata (Książkiewicz, 1977) & & - & & • & • & & & & • & & \\
\hline Ophiomorpha rudis (Książkiewicz, 1977) & & $\bullet$ & & - & $\bullet$ & • & & & - & & \\
\hline Ophiomorpha isp. & $\bullet$ & $\bullet$ & & $\bullet$ & $\bullet$ & & & & $\bullet$ & & $\bullet$ \\
\hline Paleodictyon croaticum Uchman, 1995 & & & & - & & & & & & $\bullet$ & \\
\hline Paleodictyon delicatulum Uchman, 1995 & & & & & & & & & & $\bullet$ & \\
\hline Paleodictyon majus Meneghini in Peruzzi, 1880 & & & & & & $\bullet$ & & & & - & \\
\hline Paleodictyon minumum Sacco, 1888 & & & & $\bullet$ & & & & & & & \\
\hline Paleodictyon Savi \& Meneghini, 1850 & & & • & & & & & & & $\bullet$ & \\
\hline Paleodictyon strozzii Savi \& Meneghini, 1850 & & & & - & • & & & & & $\bullet$ & \\
\hline Paleodictyon cf. strozzii Meneghini, 1850 & & & & & & $\bullet$ & & & & & \\
\hline Palaeophycus tubularis Hall, 1847 & & - & & & & & & & & & \\
\hline Phymatoderma Brongniart, 1849 & & & & & & & & & & $\bullet$ & \\
\hline Planolites beverleyensis (Billings, 1862) & & & & & & & & & $\bullet$ & & \\
\hline ?Planolites isp. & & - & & & $\bullet$ & $\bullet$ & - & & & & - \\
\hline Planolithus isp. & & & & $\bullet$ & & & & & & & $\bullet$ \\
\hline Protopaleodictyon submantanum Azpeitia \& Moros, 1933 & & & & & & & & & & $\bullet$ & \\
\hline Rhizocorallium isp. & & & & & & & & & $\bullet$ & & \\
\hline Rutichnius isp. & & & & $\bullet$ & $\bullet$ & & & & & & \\
\hline Sabularia simplex Książkiewicz, 1977 & & & $\cdot$ & & & & & & & & \\
\hline Scolicia isp. & & $\bullet$ & & & & & $\bullet$ & & & & \\
\hline Scolicia plana Książkiewicz, 1970 & & & $\bullet$ & & $\bullet$ & $\bullet$ & & & $\bullet$ & & \\
\hline Scolicia prisca de Quatrafages, 1849 & & & & $\bullet$ & $\bullet$ & & & & $\bullet$ & & \\
\hline Scolicia strozzii (Savi \& Meneghini, 1850) & & & & • & $\bullet$ & $\bullet$ & & & • & & \\
\hline Scolicia vertebralis Książkiewicz, 1970 & & $\bullet$ & & $\bullet$ & $\bullet$ & & & & $\bullet$ & & \\
\hline Skolithos isp. & & $\bullet$ & & & & & & & & & - \\
\hline Spirorhaphe involuta (de Stefani, 1895) & & & $\bullet$ & & & & & & & & \\
\hline Subphyllochorda striata Książkiewicz, 1970 & & & $\bullet$ & & & & & & & & \\
\hline Taphrhelminthopsis isp. & & & • & & & & & & & & \\
\hline Thalassinoides isp. & $\bullet$ & $\bullet$ & & & $\bullet$ & $\bullet$ & $\bullet$ & & $\bullet$ & & $\bullet$ \\
\hline Urohelminthoida dertonensis Sacco, 1888 & & & & & & - & & & - & • & \\
\hline Urohelminthoida isp. & & & & & & & & & - & & \\
\hline Zoophycos brianteus Massalongo, 1855 & & & • & & & & & & & & \\
\hline Zoophycos isp. & & & & & • & & & & • & & \\
\hline
\end{tabular}

Cross-cutting relations between trace fossils in the İncesu Formation are common. In general, the specimens of Palaeophycus tubularis and Planolites beverleyensis may be cut by Scolicia isp. The latter shows intraspecific cross-cutting. Scolicia isp. is also seen to cross-cut Thalassinoides $\mathrm{cf}$. suevicus.

\section{Discussion: Ethology and ichnofacies}

Models of behavioural activity in deeper marine successions, and the diversity of trace fossils, are based on only a few detailed studies. The trace fossil assemblages only indirectly show the absolute bathymetry; however, the assemblages 
may also indicate other environmental parameters such as food supply, sedimentation rate, oxygenation and salinity (e.g., Bromley \& Ekdale 1984). In the following discussion we provide an overview of the recognized ichnofacies and an interpretation of the palaeoenvironments. The ichnofacies scheme was originally initiated by Seilacher (1964b, 1967) and elaborated further by others (e.g., Bromley et al. 1984, Bromley \& Asgaard 1991, Buatois \& Mángano 2004).

Isparta Çay Formation. - The Triassic to Early Cretaceous sediments in the Ağilköy area (locality 1) contain graphoglyptid trace fossils typically found on the erosive undersides of flysch turbidites (Table 1, Fig. 5). The absence of cross-cutting trace fossils suggests that the trace makers avoided re-burrowing previous parts of the traces. The trace fossils are elaborated structures (e.g., Paleodictyon arvense) with open tunnel systems, which may have become repeatedly revisited. These structures are assumed to have served as "gardens" for microbial symbionts exploring the surrounding sediment for nutrients (e.g., Seilacher 1992). The tunnel walls may have been lined with mucus. The meandering trace fossils, Helminthopsis isp. and Helminthorhaphe flexuosa, are also considered to have formed as open tunnels. The open tunnels may have functioned as drainage systems (Seilacher 2007). Meandering trace fossils have previously been interpreted as burrows of deposit feeders. The trace fossil assemblage found in the Ağilköy area is assigned to the Nereites ichnofacies. Periodically the hydrodynamic energy level was high and traces in a certain tiering depth became partly eroded by turbiditic flow and filled with sand. In this way, the Nereites ichnofacies were formed by a combination of biological and taphonomical contributions (Bromley \& Asgaard 1991).

Koçtepe Formation. - The Middle Paleocene to Early Eocene successions consist of sandstones and marly intervals. The latter represent the time intervals of deposition when the rates of sedimentation and sediment accumulation reached the lowest values, and starvation reached a maximum. The low diversity and density of trace fossils may indicate stressful living conditions for the trace makers. Scolicia is reflective of a mode of burrowing in which the sediment is moved from the front, passed along the exterior of the trace maker's body, and deposited as meniscoid backfill structure behind. Post-Jurassic specimens are known to have been produced by irregular echinoids (Spatangoidea) (e.g., Bromley \& Asgaard 1975, Seilacher 1992, Nielsen et al. 2008). The winding behaviour is an efficient approach to explore the food-bearing sediment (Seilacher 1992). Scolicia ?vertebralis found at the Göltaș cement factory (locality 3 ) shows examples of the behavioural pattern phobotaxis (Fig. 8). The trace makers utilised an avoidance strategy to prevent re-burrowing previous trace sections (Richter 1928, Simpson 1957, Osgood 1970). Crossings are usually absent. Similar behaviour is recognized in specimens of Chondrites from the northern Isparta Angle (this study). The trace makers may have used chemoreceptors for phobotaxis (Osgood 1970). In addition, Scolicia ?vertebralis exhibits closely spaced meanders reflecting efficient exploitation (thigmotaxis) and periodical reverse turns (strophotaxis) (Richter 1928, Osgood 1975).

Nereites isp. was found at locality 2. Nereites reflects the burrowing action of an unknown worm-like sediment feeder (enteropneust?) that proceeded through the sediment at the head and end before stowing it in lobes around the body (Seilacher 1992). The cavity behind the body became backfilled to form a core of sediment enveloped by an even or lobate mantle (Uchman 1995, 1998). Overall, the trace fossil assemblage at the Göltaș cement factory (locality 3) indicates the presence of the Nereites ichnofacies.

Another trace fossil assemblage is present close to locality 2 (Table 1, Fig. 7). The assemblage contains Polykladichnus isp. and Arenicolites sparsus which occur sporadically at a low density. The distribution may indicate sedimentation dynamics mostly governed by alternating low and high levels of hydrodynamic energy. The presence of small-scale primary sedimentary structures indicates similar depositional conditions with colonization windows available for opportunistic trace makers in periodically mobile substrate. The deposits are therefore allocated to the Arenicolites ichnofacies. This ichnofacies represents short-term post-event colonization in deposits of deep-marine environments, in addition to non-marine, shallow-marine and offshore settings (e.g., Bromley \& Asgaard 1991). The Arenicolites ichnofacies has been considered as unrepresentative of the variation and diversity of trace fossil assemblages in tempestite beds (sensu Frey \& Goldring 1992, Goldring 1995). In addition Arenicolites reflects behaviour other than opportunistism. According to Buatois \& Mángano (2004), assemblages of Arenicolites ichnofacies can be difficult to distinguish from those of Skolithos ichnofacies. However, the usefulness of the Arenicolites ichnofacies has been demonstrated (e.g., Bann \& Fielding 2001, Buckman 1992, Singh 2009). Ethologically Arenicolites is representative of the category domichnion (e.g., Bromley 1996, Moghadam \& Paul 2000, Šimo \& Olšavský 2007). Specimens of Polykladichnus within marine deposits are interpreted as domichnia of polychaetes or cerianthid anemones (Schlirf \& Uchman 2005).

Isparta Formation. - The Early to Middle Eocene Isparta Formation has a low density of trace fossils (localities 4 and 5), which indicates a depositional environment stressful to trace makers, and probably with low preservation potential for traces (Fig. 9). The presence of Helminthopsis isp. and Ophiomorpha rudis implies a deeper marine palaeoenvironment where current flows caused the scouring and casting of the traces. Sedimentation rates and frequency of 
abrupt deposition were primary parameters. This led to coarse-grained graded beds of turbiditic origin. Helminthopsis isp. was formed by a mobile trace maker burrowing through the sediment. The trace fossil reflects repichnial behaviour. Ophiomorpha rudis can be interpreted as fodinichnion, formed as an open burrow system. Uchman (2009) suggested that the trace makers farmed microbes on phytodetritus at the redox boundary. The trace fossil assemblage of the Isparta Formation has a low ichnodiversity and ichnotaxonomically resembles the Ophiomorpha rudis ichnosubfacies as defined by Uchman (2009). This ichnosubfacies is part of the Nereites ichnofacies. The Isparta Formation was deposited as a proximal deep-marine fan with coarse-grained sediments. In comparison, the Ophiomorpha rudis ichnosubfacies has been recorded from channel and proximal depositional lobe facies of deep-sea fans. In addition, the ichnosubfacies may occur in thick interbedded facies of deep-sea clastic ramps (Uchman 2009).

Incesu Formation. - The Middle Eocene to Early Oligocene İncesu Formation contains a variety of trace fossil indicating well-oxygenated interstitial water and readily available food. At Gönen Kale Hill (locality 6), the trace fossil assemblage is characterised by fodinichnia such as Palaeophycus tubularis, Thalassinoides cf. suevicus and Zoophycos isp. (Table 1, Fig. 10). Pascichnial trace fossils are also common and include Scolicia isp. and Planolites ispp. Horizontal trace fossils prevail. The sediments are intensively bioturbated. The trace fossil assemblage is typical of the Zoophycos ichnofacies that was formed in relatively low-energy offshore depositional settings with a low to moderate sedimentation rate. The deposition is likely to have taken place in an outer shelf environment.

Overall, the trace fossil assemblages of the investigated formations indicate depositional conditions including substrate consistency and stability, events of gentle erosion and filling, and oxygenation levels. The density, diversity and preservation of the trace fossils successfully show the sedimentation history. These yield important new results about the Lake District in the northern Isparta Angle.

\section{Ichnology of other regions in Turkey}

Based on the previous literature, ichnological data from Turkey can be summarised in the following synthesis (Table 2). Trace fossils formed by bioturbational conditions were recorded from Maastrichtian-Paleocene sediments in the Bolu region (Sevim 2003); the Paleogene sediments in the Elazığ region (Özkul 1993), in the Thrace (Demircan 2008); the Miocene sediments in the Adana Basin (Uchman \& Demircan 1999a, b; Demircan \& Toker 2003, 2004), in the Mut (Mersin) Basin (Uchman et al. 2002); Pliocene-Pleistocene sediments in the Mut (Mersin)
Basin (Y1ldiz et al. 2003) (Fig. 1). Microscopic bioerosion records come from the Maastrichtian sediments from the Bilecik, Bolu, Ankara, Isparta, Malatya and Adiyaman regions (Görmüț \& Sagular 1998, Görmüț \& Meriç 2000, Meriç \& Görmüș 2001, Nielsen \& Görmüș 2004, Görmüș et al. 2005, Görmüș \& Nielsen 2006) (Fig. 1). A comparison with these investigations relies on two main factors. First, the biostratigraphical age of the deposits must be assumed to be accurately recognized from their content of indicator taxa. Second, the observed trace fossils are correctly assigned to ichnotaxa. The latter presupposes that the trace fossils are sufficiently well preserved to reveal diagnostic morphological features.

\section{Conclusions}

The Triassic to early Cretaceous and Paleocene to Oligocene trace fossils from southwestern Turkey presented in this paper provide a data set which highlights the different depositional conditions of shelf environments in relation to deep-marine shelf slope environments. The integration of ichnology with classical sedimentology has improved the understanding of the Neotethys sedimentary successions at Eğirdir, Gönen and Isparta within the Isparta Angle. The successions are characterized by a predominance of primary physical sedimentary structures, and subordinance or even absence of skeletal and shelly assemblages. The biogenic sedimentary structures, i.e., traces, were strongly controlled by the prevailing environment. The Isparta Çay Formation and its trace fossils are interpreted as Paleodictyon ichnosubfacies of the Nereites ichnofacies. The Koçtepe Formation contains two distinct trace fossil assemblages, which comprise the Nereites and Arenicolites ichnofacies. The trace fossil assemblage of the Isparta Formation can be assigned to the Ophiomorpha rudis ichnosubfacies of the Nereites ichnofacies. The development of ichnofacies indicates that the Isparta Çay, Koçtepe and Isparta formations formed in deep-marine environments with different sedimentary regimes. The İncesu Formation and its trace fossils are interpreted as Zoophycos ichnofacies from a shelf setting in the Neotethys ocean.

\section{Acknowledgements}

The senior author wishes to thank Mustafa Kușcu and other staff of the Jeoloji Mühendisliği Bölümü at the Süleyman Demirel University for hospitality during a visiting professorship. For help during fieldwork, we wish to express our sincere thanks to Cüneyt Bircan and Onur Tunç (Çomu, Turkey). Thanks also go to Alfred Uchman (Jagiellonian University, Kraków), Jesper Kresten Nielsen (SINTEF Petroleum Research, Trondheim), Vladimír Šimo (Slovak Academy of Sciences) and an anonymous reviewer for critically reading and suggesting improvements to the paper. 


\section{References}

AKBULUT, A. 1980. Eğirdir Gölü güneyinde Çandýr (Sütçüler, Isparta) yöresindeki Batý Toroslarýn jeolojisi. Türkiye Jeoloji Bülteni 23, 1-9.

AKKIRAZ, M.S., AKGÜN, F. \& ÖRÇEN, S. 2007. Batı Toroslarýn kuzeyindeki İncesu Havzasının Oligosen palinostratigrafisi ve paleoiklimi, Isparta Çevresi, Türkiye. 60. Türkiye Jeoloji Kurultayı, bildiri özleri, 385-387.

AllasinaZ, A, GuTNIC, M. \& POISSON, A. 1974. La formation de l'Isparta Cay calcaires à Halobies, grés à plantes, et radiolarites d'age Carnien(?) Norie (Taurides-Region d'Isparta-Turquie). Schriftenreihe der Erdwissenschaftlichen Kommissionen, Österreichische Akademie der Wissenschaften 2, 11-21.

BANN, K.L. \& FIELDING, C.R. 2001. High-resolution sequence stratigraphy of reservoirs in the Bowen Basin, Queensland, Australia, facilitated by ichnological analysis. AAPG Annual Convention, June 3-6, 2001, Denver, Colorado. Abstracts.

Bertling, M., Braddy, S., Bromley, R.G., Demathieu, G.D., Genise, J., Mikuláš, R., Nielsen, J.K., Nielsen, K.S.S., RiNDSBERG, A., SCHLIRF, M. \& UCHMAN, A. 2006. Names for trace fossils: a uniform approach to concepts and procedures. Lethaia 39, 265-286. DOI 10.1080/00241160600787890

BROMLEY, R.G. 1996. Trace fossils: biology, taphonomy and applications. $2^{\text {nd }}$ edition. 361 pp. Chapman \& Hall, London.

BROMLEY, R.G. \& ASGAARD, U. 1975. Sediment structures produced by a spatangoid echinoid: a problem of preservation. Bulletin of the Geological Society of Denmark 24, 261-281.

BROMLEY, R.G. \& ASGAARD, U. 1991. Ichnofacies: a mixture of taphofacies and biofacies. Lethaia 24, 153-163. DOI 10.1111/j.1502-3931.1991.tb01463.x

BRomley, R.G. \& EKDALE, A.A. 1984. Chondrites: A trace fossil indicator of anoxia in sediments. Science 224, 872-874. DOI 10.1126/science.224.4651.872

Bromley, R.G., Pemberton, S.G. \& RAhMANI, R.A. 1984. A Cretaceous woodground: The Teredolites ichnofacies. Journal of Paleontology 58, 488-498.

BuAtois, L.A. \& MÁngano, M.G. 2004. Ichnology of fluvio-lacustrine environments: animal-substrate interaction in freshwater ecosystems. Geological Society of London, Special Publication 228, 311-333.

BUCKMAN, J.O. 1992. Palaeoenvironment of a Lower Carboniferous sandstone succession northwest Ireland: ichnological and sedimentological studies. Geological Society, Special Publications 62, 217-241.

DEMIRCAN, H. 2008. Trace fossil associations and palaeoenvironmental interpretation of the late Eocene units (SW-Thrace). Bulletin of the Mineral Research and Exploration 136, 29-47.

DEMIRCAN, H. \& TOKER, V. 2003. Trace fossils in the western fan of the Cingöz Formation in the northern Adana basin (southern Turkey). Bulletin of the Mineral Research and Exploration 127, 15-32.

DEMIRCAN, H. \& TOKER, V. 2004. Cingöz Formasyonu doğu yelpaze iz fosilleri (KB Adana). Maden Tetkik Arama Enstitüsü Dergisi 129, 69-87.

DoĞDU, B.E. 2007. Haymana Güneyi (Ankara) Yamak
Formasyonu iz fosilleri. 101 pp. Yüksek Lisans Tezi, Ankara Üniversitesi, Fen Bilimleri Enstitüsü, Türkiye.

Dumont, J.F., Gutnic, M., MARCouX, J., MONOD, O. \& POISSON, A. 1972. Le Trias des Taurides occidentales (Turquie). Definition du bassin pamphylien: Un nouveau domaine à ophiolites à la marge externe de la chaine taurique. Zeitschrift der Deutschen Geologischen Gesellschaft 123, 385-409.

FREY, R.W. \& GOLDRING, R. 1992. Marine event beds and recolonization surfaces as revealed by trace fossil analysis. Geological Magazine 129, 325-335. DOI 10.1017/S0016756800019269

FÜRSICH, F.T. 1981. Invertebrate trace fossils from the Upper Jurassic of Portugal. Comunicações dos Serviços Geológicos de Portugal 67, 153-168.

GLOVER, C.P. \& ROBERTSON, A.H.F. 1998. Role of regional extension and uplift in the Plio-Pleistocene evolution of the Aksu Basin, SW Turkey. Journal of the Geological Society 155, 365-387. DOI 10.1144/gsjgs.155.2.0365

GOLDRING, R. 1995. Organisms and the substrate: response and effect. Geological Society, London, Special Publication 83, 151-180.

GOLDRING, R. \& POLLARD, J.E. 1996. Ichnotaxonomic revision and the importance of type material. Palaeontology Newsletter 31, 7-8.

GÖrmÜȘ, M., CARAN, Ș., ÇOBAn, H. \& YillmaZ, K. 2001 b. Bedre-Barla (Eğirdir Gölü Batısı) arasında kıyı kenar çizgisi. 1. Eğirdir Sempozyumu, 31 A ğustos-1 Eylül 2001, Bildiriler, Isparta, 387-402.

GÖRMÜȘ, M. \& KARAMAN, E. 1992. Facies changes and new stratigraphical-paleontological data in the Cretaceous-Tertiary boundary around Söbüdağ (Çünür-Isparta). Çukuova University Geosound 21, 43-57.

GÖRMÜȘ, M. \& MERIÇ, E. 2000. Unusual forms of orbitoidal foraminifera in the Maastrichtian of Turkey. Cretaceous Research 21, 801-812. DOI 10.1006/cres.2000.0230

GÖRMÜȘ, M., MERIÇ, E., UYSAL, K. \& NIELSEN, J.K. 2005. Orbitoides kavkılarındaki izlere ait yeni bulgular ve bu izlerin ortamsal önemi. Çukurova Üniversitesi Geosound 46, 25-40.

GÖRMÜȘ, M. \& NIELSEN, J.K. 2006. Borings in large benthic foraminifers from Turkey and their palaeoenvironmental significance. Journal of Foraminiferal Research 36, 152-165. DOI 10.2113/36.2.152

GÖRMÜȘ, M., NIELSEN, J.K. \& UYSAL, K. 2003. Trace fossils from Tertiary sediments between Gönen (Isparta)-Ağlasun (Burdur). 20 $0^{\text {th }}$ Anniversary Geology Symposium, Süleyman Demirel Üniversitesi, May 14-16, 2003, Isparta. Abstracts, 64-65.

GÖRMÜȘ, M., NIELSEN, J.K. \& UYSAL, K. 2008. Ichnology of Tertiary deposits from the Lake District, southwestern Turkey: sedimentation dynamics and oxygenation. $33^{\text {rd }}$ International Geological Congress, Oslo, Aug. 6-14, 2008. Abstract CD-ROM.

GÖRMÜș, M. \& ÖZKUL, M. 1995. Gönen-Atabey (Isparta) ve Ağlasun (Burdur) arasýndaki Bölgenin Stratigrafisi. Süleyman Demirel Üniversitesi, Fen Bilimleri Enstitüsü Dergisi 1, 43-64.

GÖRMÜȘ, M. \& SAGULAR, E.K. 1998. Microboring activity in Orbitoides accumulations from Turkey. Israel Journal of Earth Science 47, 61-67. 
GÖRMÜȘ, M., SAGULAR, E.K. \& ÇOBAN, H. 2001a. The Miocene sequence characteristics, its contact relation to the older rocks and lamprophyric dikes in the Dereboğazı area (southern Isparta, Turkey). $4^{\text {th }}$ International Symposium on Eastern Mediterranean Geology, 21-25 May 2001, Proceedings, Isparta, 69-90.

Gutnic, M., Monod, O., Poisson, A. \& Dumont, J. F. 1979. Geologie des Taurides occidentales (Turquie). Memories Société géologique de France 137, 1-112.

HEDBERG, H.D. 1976. International stratigraphic guide. 187 pp. John Wiley and Sons, New York.

KARAMAN, M.E., MERIÇ, E. \& TANSEL, İ. 1988. Çünür (Isparta) dolaylarında Kretase-Tersiyer geçiși. Akdeniz Üniversitesi Isparta Mühendislik Fakültesi Dergisi 4, 80-100.

KARAMAN, M.E. 1990. Isparta güneyindeki sahanın jeolojik etüdü. Türkiye Jeoloji Bülteni 33, 57-67.

KARAMAN, M.E. 1994. Isparta-Burdur arasinın jeolojisi ve tektonik özellikleri. Türkiye Jeoloji Bülteni 37, 57-68.

KoÇYIĞIT, A. 1980. Hoyratı gölü yöresinin (Afyon-Isparta) stratigrafik ve tektonik šzellikleri. 172 pp. Doçentlik tezi, Ankara Üniversitesi, Fen Fakültesi Genel Jeoloji Kürsüsü, Türkiye.

KoÇYIĞIT, A. 1981. Isparta Büklümünde (batı Toroslar) Toros karbonat platformunun evrimi. Türkiye Jeoloji Kurumu Bülteni 24, 15-23.

KoÇYIĞIT, A. 1983. Hoyran Gölü (Isparta Büklümü) Dolayýnýn Tektoniği. Türkiye Jeoloji Kurumu Bülteni 26, 1-10.

KoÇYIĞIT, A. 1984. Güneybatı Türkiye ve komșu sahaların levha içi Neotektonik gelișimi. Türkiye Jeoloji Kurumu Bülteni 27, $1-16$.

KOÇYIĞIT, A. 2000. Güneybatı Türkiye'nin depremselliği. BADSEM 2000-Batı Anadolu'nun Depremselliği Sempozyumu, 24-27 Mayıs 2000, Bildiriler, İzmir, 30-39.

MERIÇ, E. \& GÖRMÜș, M. 2001. The genus Loftusia. Micropaleontology, supplement 1, 1-71.

MoghadAM, H.V. \& PAUL, C.R.C. 2000. Trace fossils of the Jurassic, Blue Lias, Lyme Regis, southern England. Ichnos 7, 283-306. DOI 10.1080/10420940009380167

MONOD, O. 1976. La courbe d'Isparta: une mosaique de blocks autochtones surmonté de nappes composites à la jonction de l'arc Hellenique et de l'arc Taurique. Bulletin de la Société Géologique de France 18, 521-531.

NIELSEN, J.K. \& GÖRMÜȘ, M. 2004. Ichnotaxonomy and ethology of borings in shallow-marine benthic foraminifers from the Maastrichtian and Eocene of Northwestern and Southwestern Turkey. Rivista Italiana di Paleontologia e Stratigrafia 110, 493-501.

NiElSEN, J.K., HANSEN, K.S. \& SiMONSEN, L. 1996. Sedimentology and ichnology of the Robbedale Formation (Lower Cretaceous), Bornholm, Denmark. Bulletin of the Geological Society of Denmark 43, 115-131.

NIELSEN, K.S.S. \& NIELSEN, J.K. 2001. Bioerosion in Pliocene to late Holocene tests of benthic and planktonic foraminiferans, with a revision of the ichnogenera Oichnus and Tremichnus. Ichnos 8, 99-116. DOI 10.1080/10420940109380178

NiELSEN, J.K., NiELSEN, J.K., HELAMA, S. \& WORTHINGTON, R. 2008. Ichnofabrics as evidence of depositional dynamics on a prograding carbonate wedge: an example from the Pleis- tocene of Rhodes, Greece. $33^{\text {rd }}$ International Geological Congress, Oslo, Aug. 6-14, 2008. Abstract CD-ROM.

OsGOOD, R.G., Jr. 1970. Trace fossils of the Cincinnati Area. Palaeontographica Americana 6, 281-444.

OSGOOD, R.G., Jr. 1975. The paleontological significance of trace fossils, 87-108. In FREY, R.W. (ed.) The study of trace fossils. A synthesis of principles, problems, and procedures in ichnology. Springer-Verlag, New York.

ÖZKUL, M. 1993. Kırkgeçit Formasyonunda (Eosen, Elazýğ) fliş iz fosilleri ve ortamsal dağılımlarý. Akdeniz Üniversitesi Isparta Mühendislik Fakültesi Dergisi 7, 15-30.

Poisson, A. \& PoignANT, A.F. 1974. La formation de Karabayır, base de la transgression miocène dans la région de Korkuteli (Antalya, Turquie). Lithothamnium pseudoramossissimum: nouvelle espèce d'algue rouge de la formation de Karabayır. Mineral Research and Exploration Bulletin 82, $67-71$.

POISSON, A. 1977. Recherches géologiques dans les Taurides Occidentales (Turquie). 795 pp. Doctorat d'état thesis, Université de Paris-Sud, Orsay, France.

Poisson, A., YAĞMurlu, F., BozCU, M. \& ȘEnTÜRK, M. 2003a. New insights on the tectonic setting and evolution around the apex of the Isparta Angle (SW Turkey). Geological Journal 38, 257-282. DOI 10.1002/gj.955

Poisson, A., WeRnli, R., SAgular, E.K. \& TEMiz, H. 2003b. New data concerning the age of the Aksu Thrust in the south of the Aksu Valley, Isparta Angle (SW Turkey): consequences for the Antalya Basin and the Eastern Mediterranean. Geological Journal 38, 311-328. DOI 10.1002/gj.958

RICHTER, R. 1928. Psychische Reaktionen fossiler tiere. Helminthoiden und Nereiten als Fragen der Fährtenkunde an die Tierpsychologie. Palaeobiologica 1, 225-244.

RINDSBERG, A.K. \& KOPASKA-MERKEL, D.C. 2005. Treptichnus and Arenicolites from the Steven C. Minkin Paleozoic Footprint Site (Langsettian, Alabama, USA), 121-141. In BUTA, R.J., RINDSBERG, A.K. \& KOPASKAMerkel, D.C. (eds) Pennsylvanian footprints in the Black Warrior Basin of Alabama. Alabama Paleontological Society Monograph 1.

RoBERTSON, A.H.F. 1993. Mesozoic-Tertiary sedimentary and tectonic evolution of Neotethyan carbonate platforms, margins and small ocean basins in the Antalya Complex, southwest Turkey. Special Publication, International Association of Sedimentologists 20, 415-465.

ROBERTSON, A.H.F. 2000. Mesozoic-Tertiary tectonic-sedimentary evolution of a south Tethyan oceanic basin and its margins in the southern Turkey. Geological Society of London, Special Publication 173, 97-138.

RoBERTSON, A.H.F., POISSON, A. \& AKINCI, Ö. 2003. Developments in research concerning Mesozoic-Tertiary Tethys and neotectonics in the Isparta Angle, SW Turkey. Geological Journal 38, 195-234. DOI 10.1002/gj.953

SAGULAR, E.K. \& GÖRMÜș, M. 2006. New stratigraphical results and evidence of reworking based on nannofossils, foraminiferal and sedimentological data in the Eocene sequence from the Derebogazi area, N Isparta Angle, SW Turkey. Journal of Asian Earth Sciences 27, 78-98.

DOI 10.1016/j.jseaes.2005.02.002

SALTER, J.W. 1857. On annelide-burrows and surface-markings 
from the Cambrian rocks of the Longmynd. No. 2. Quarterly Journal of the Geological Society 13, 199-206.

DOI 10.1144/GSL.JGS.1857.013.01-02.29

SARIIZ, K. 1985. Keçiborlu kükürt yataklarının oluțumu ve yörenin jeolojisi. Doktora tezi, Anadolu Üniversitesi yayınları, Yayın no. 91, Eskișehir.

SCHLIRF, M. \& UCHMAN, A. 2005. Revision of the ichnogenus Sabellarifex Richter, 1921 and its relationship to Skolithos Haldeman, 1840 and Polykladichnus Fürsich, 1981. Journal of Systematic Palaeontology 3, 115-131. DOI 10.1017/S1477201905001550

SEILACHER, A. 1964a. Sedimentological classification and nomenclature of trace fossils. Sedimentology 3, 253-256.

SEILACHER, A. 1964b. Biogenic sedimentary structures, 296-316. In IMBRIE, J. \& NeWELL, N. (eds) Approaches to paleoecology. John Wiley \& Sons, New York.

SEILACHER, A. 1967. Bathymetry of trace fossils. Marine Geology 5, 413-428. DOI 10.1016/0025-3227(67)90051-5

SEILACHER, A. 1992. Vendobionta: strangest organisms on Earth and evolution of trace fossils, 57-73. In ÁlVAREZ, F. \& MORRIS, S.C. (eds) Lecture course on palaeobiology: preparing for the twenty-first century. Instituto Juan March de Estudios e Investigaciones, Centro de Reuniones Internacionales sobre Biología, Madrid.

SEILACHER, A. 2007. Trace fossil analysis. 226 pp. SpringerVerlag, Berlin.

ȘENEL, M. 1984. Discussion on the Antalya nappes, 41-52. In TEKELI, O. \& GÖNCÜOĞLU, M.C. (eds) Geology of Taurus Belt. Proceedings of International Symposium on the Taurus Belt, 1983. Mineral Research and Exploration Institute (MTA) of Turkey Publication.

ȘENEL, M. 1997. 1:250000 ölçekli Türkiye Jeoloji Haritaları No: 4, Isparta paftası. 47 pp. Maden Tetkik Arama Enstitüsü Jeoloji etüdleri dairesi, Ankara.

ȘENTÜRK, M. \& YAĞMURLU, F. 2003. Acıgöl ve Burdur arasýndaki bölgenin jeolojik ve sismotektonik özellikleri. Süleyman Demirel Üniversitesi, Fen Bilimleri Enstitüsü Dergisi 7, Özel say1, 11-24.

SEVIM, S. 2003. Göynük (Bolu) - Taraklı (Adapazarý) bölgelerinin Kretase-Tersiyer sinırının iz fosilleri ve nannoplankton biyostratigrafisi. 159 pp. Yüksek lisans tezi, Ankara Üniversitesi, Türkiye.

ŠIMO, V. \& OLŠAVSKÝ, M. 2007. Diplocraterion parallelum Torell, 1870, and other trace fossils from the Lower Triassic succession of the Drienok Nappe in the western Carpathians, Slovakia. Bulletin of Geosciences 82, 165-173. DOI 10.3140/bull.geosci.2007.02.165

SIMPSON, S. 1957. On the trace-fossil Chondrites. The Quarterly Journal of the Geological Society of London 107, 475-499.

SINGH, B.P. 2009. Integrated ichnological and sedimentological Studies of the Parahio Formation (Cambrian) of the Zanskar region (Zanskar-Spiti Basin), Northwest Himalaya. Journal Geological Society of India 74, 723-737. DOI 10.1007/s12594-009-0189-3

TEKIN, U.K. 1999. Biostratigraphy and systematics of late middle to late Triassic radiolarians from the Taurus Mountains and
Ankara Region, Turkey. Geologisch-Paläontologische Mitteilungen Innsbruck Sonderband 5, 1-297.

TEMIZ, H., POISSON, A. \& ANDRIEUX, J. 2001. The Plio-Quaternary extensional system of the western side of the Isparta Angle in SW Turkey. $4^{\text {th }}$ International Symposium Eastern Mediterranean Geology, Isparta. Abstracts, 125-129.

UCHMAN, A. 1995. Taxonomy and palaeoecology of flysch trace fossils: The Marnoso-arenacea Formation and associated facies (Miocene, Northern Apennines, Italy). Beringeria 15, 3-115.

UCHMAN, A. 1998. Taxonomy and ethology of flysch trace fossils: A revision of the Marian Książkiewicz collection and studies of complementary material. Annales Societatis Geologorum Poloniae 68, 105-218.

UCHMAN, A. 2009. The Ophiomorpha rudis ichnosubfacies of the Nereites ichnofacies: Characteristics and constraints. Palaeogeography, Palaeoclimatology, Palaeoecology 276, 107-119. DOI 10.1016/j.palaeo.2009.03.003

UCHMAN, A. \& DEMIRCAN, H. 1999a. A Zoophycos group trace fossil from Miocene flysch in southern Turkey: evidence for a U-shaped causative burrow. Ichnos 6, 251-259.

DOI 10.1080/10420949909386456

UChMAN, A. \& DEMIRCAN, H. 1999b. Trace fossils of Miocene deep-sea fan fringe deposits from the Cingöz Formation, southern Turkey. Annales Societatis Geologorum Poloniae 69, 125-135.

UChman, A., Demircan, H., TOKer, V., DeRman, A.S., SEVIM, S. \& SZULC, J. 2002. Relative sea-level changes recorded in borings from a Miocene rocky shore of the Mut Basin, southern Turkey. Annales Societatis Geologorum Poloniae 72, 263-270.

VRIELYNCK, B., BONNEAU, M., DANELIAN, T., CADET, J.P. \& POISSON, A. 2003. New insights on the Antalya Nappes in the apex of the Isparta Angle: the Isparta Çay unit revisited, Geological Journal 38, 283-293. DOI 10.1002/gj.956

YAGMURLU, F., SAVASCIN, M.Y. \& ERGUN, M. 1997. Relation of alkaline volcanism and active tectonism within the evolution of Isparta Angle, SW Turkey. The Journal of Geology 15, 717-728. DOI 10.1086/515978

YalçINKAYA, S., ERGin, A., AfȘAR, Ö.P. \& TANER, K. 1986. Batı Torosların jeolojisi, Isparta projesi raporu. MTA Genel Müdürlüğü Raporları, Ankara.

YALÇINKAYA, S. 1989. Isparta-Ağlasun (Burdur) dolaylarýnýn jeolojisi. 176 pp. Doktora tezi, İstanbul Universitesi, Fen Bilimleri Enstitüsü.

YeșiLOT, S.K. 2000. Dinar-Isparta arasindaki Eosen bentik foraminiferlerinin sistematik ve biyofabrik incelemesi. $116 \mathrm{pp}$. Yüksek lisans tezi, Süleyman Demirel Üniversitesi, Fen Bilimleri Enstitüsü.

Yildiz, A., Karahasan, G., Demircan, H. \& ToKer, V. 2000. Kalecik (Ankara) güneydoğusu alt MaastrichtiyenPaleosen biyostratigrafisi ve paleoekolojisi. Yerbilimleri 22, 247-259.

YildiZ, A., TOKER, V., DEMIRCAN, H. \& SEVIM, S. 2003. Mut Havzası Pliyosen-Pleyistosen nannoplankton, planktik foraminifera, iz fosil bulguları ve paleoortam yorumu. Yerbilimleri 28, 123-144. 